\begin{tabular}{cc|c}
\hline Tar. Bil. Der. & Journal of Agricultural Sciences \\
& $\begin{array}{c}\text { Dergi web sayfası: } \\
\text { www.agri.ankara.edu.tr/dergi }\end{array}$ & Journal homepage: \\
& www.agri.ankara.edu.tr/journal
\end{tabular}

\title{
Türkiye'de Süt Ürünleri Tüketim Harcamalarına Etki Eden Faktörlerin Analizi: Çoklu Heckman Örneklem Seçicilik Sistem Yaklaşımı
}

\author{
Mustafa TERIIN ${ }^{\mathrm{a}}$, Abdulbaki BILGGíç ${ }^{\mathrm{b}}$, İrfan Okan GÜLER ${ }^{\mathrm{b}}$, Fahri YAVUZ $^{\mathrm{b}}$

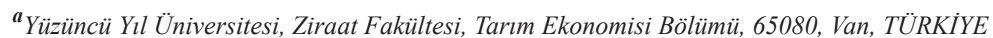 \\ ${ }^{\boldsymbol{b}}$ Atatürk Üniversitesi, Ziraat Fakültesi, Tarım Ekonomisi Bölümü, 25240, Erzurum, TÜRKIYE

\section{ESER BILGISII} \\ Araştırma Makalesi \\ DOI: 10.1501/Tarimbil_0000001353 \\ Sorumlu Yazar: Abdulbaki BiLGICC, E-posta: abilgic@atauni.edu.tr, Tel: +90 (442) 2312589 \\ Geliş Tarihi: 04 Temmuz 2014, Düzeltmelerin Gelişi: 27 Eylül 2014, Kabul: 02 Ekim 2014
}

\begin{abstract}
ÖZET
Bu çalışmada Türkiye'de ekonomik büyüme ile sağlanan gelir artışının ve diğer sosyo-demografik ve ekonomik faktörlerin hane halkı süt ve süt ürünleri tüketim harcamalarına etkileri analiz edilmiştir. Bu amaca ulaşmada Çoklu Heckman Seçicilik Modeli (HSM) kullanılmıştır. Çoklu HSM'de her bir ürüne yapılan harcama olasılığı ile harcama düzeyleri ve çapraz korelasyonlar varsayımı altında gerçekleșmektedir. Çalıșmada kullanılan veriler, Türkiye İstatistik Kurumu (TÜIK) tarafindan 2010 yılında yapılan Hane Halkı Tüketim Harcamaları anketlerinden elde edilmiştir. Örnek büyüklüğü eksik ve aykırı gözlemler çıkarıldıktan sonra 9442 kişi olarak belirlenmiştir. Araştırma sonuçlarına göre, genelde hane reisi genç (20-29 yaş) olan aileler, hane reisi 60 yaş üzeri olan ailelere göre hem kırsal hem de kentsel alanda süt ve süt ürünleri tüketim olasılığını ve tüketim harcama miktarını düşürmektedir. Ailelerin $0-5$ yaşında çocuğa sahip olması diğer yaş guruplarında çocuğa sahip olanlara göre, özellikle süt tüketim olasıllğını ve süt tüketim harcamasını önemli oranda arttırmaktadır. Gelir grubu yıllık 15-30 bin TL, 31-45 bin TL ve 45 bin TL üzerinde olanların, gelir gurubu 15 bin TL olanlara göre, peynir ve diğer süt ürünleri tüketim harcaması kentsel alanda sırasıyla $4.5 \mathrm{TL}, 9.8$ TL ve 16.6 TL kırsal alanda ise 3.6 TL, 8.0 TL ve 9.3 TL daha fazladır.
\end{abstract}

Anahtar Kelimeler: Süt ürünleri tüketimi; Heckman seçicilik modeli; Türkiye

\section{Analyzing Factors Affecting Household Milk Products' Expenditures in Turkey: A Multivariate Heckman Sample Selection System Approach}

\section{ARTICLE INFO}

Research Article

Corresponding Author: Abdulbaki BILGIC, E-mail: abilgic@atauni.edu.tr, Phone: +90 (442) 2312589

Received: 04 July 2014, Received in Revised Form: 27 September 2014, Accepted: 02 October 2014

\section{ABSTRACT}

In this study, we analyze the effects of socio-demographic and economic factors of households on the consumption of milk and milk products by considering the recent increased economic trend in Turkey. The multivariate Heckman 
sample selection system (MSS) is used to analyze the data. The likelihood of spending and levels of expenditure on each foodstuff are jointly analyzed by assuming all pairwise cross correlation. The data used in this study are obtained from Turkish Statistical Institute (TURKSTAT) of 2010 Household Consumption Expenditures Survey (HCES). After discarding missing observations and outliers from the sample, the data finally contain 9442 individual observations. Results indicate that households with younger household heads (20-29 years) as compared households with household heads aged 60 and over are less likely to spend and spend less on milk, yoghurt, cheese with other dairy products in both regions. Families with children 0-5 years old are more likely to spend and spend significantly more on dairy products than that of families with other kids combinations in both regions. Families with annual income 15-30 thousand, 31-45 thousand and 45 thousand and over in Turkish Liras (TL) as compared to the base group (families with annual income 15 thousand TL) spend more 4.5 TL, 9.8 TL and 16.6 TL respectively on cheese and other dairy products in urban area, while these figures are 3.6 TL, 8.0 TL and 9.3 TL for rural households, respectively.

Keywords: Milk products consumption; Heckman sample selection sytem; Turkey

(C) Ankara Üniversitesi Ziraat Fakültesi

\section{Giriş}

Son y1llarda Türkiye ekonomisinde yaşanan ekonomik ve siyasi istikrar, ülke ekonomisinin hızlı bir şekilde büyümesini sağlamıştır. Türkiye 20022013 y1lları arasında ortalama \% 5.08 oranında büyümeyi gerçekleştirmiştir. Hiç şüphesiz, sağlanan bu ekonomik büyüme kişi başına düşen gelirde önemli artışları beraberinde getirmiştir. 2002 yılında kişi başına düşen reel gelir 3,492 \$ iken, 2.08 kat artarak 2013 y1lında 10,782 \$ yükselmiştir (TÜİK 2014a). Gelirde meydana gelen bu artış trendi gıda tüketim talebini tetikleyeceğinden hane halklarının tüketim yapısı ve tüketim miktarlarında yıllar itibari ile önemli değişmelere neden olacaktır.

Genellikle ülkelerin gelişmişliği ve hayat standardının belirlenmesinde kişi başına düşen hayvansal protein tüketimi önemli bir ölçüt olarak kullanılmaktadır (Gögüş 1986; Yücel 2001; Yaylak et al 2010). Gelişmiş ülkelerin aksine, gelişmekte olan ülkelerde hayvansal kaynaklı gıda maddeleri tüketiminde doyuma ulaşılamamıştır. Bu nedenle, Türkiye gibi gelişmekte olan ülkelerde, kişi başına düşen gelirde meydana gelecek bir artış öncelikli olarak zorunlu gida maddesi olan ve doyuma ulaşmayan hayvansal kaynaklı gıda maddelerinin tüketiminin artmasına neden olacaktır. Tüketicilerin sosyo-ekonomik ve demografik yapıları diğer g1da ürünlerinde olduğu gibi süt ve süt ürünleri tüketimini de etkilemektedir (Akbay \& Tiryaki 2007). Türkiye'de ekonomik büyüme ile sağlanan gelir artışı, hane halkı tüketim alışkanlıkları ve tercihlerinin de zaman içerisinde değişmesine ve kişi başına düşen süt ve süt ürünleri tüketim miktarlarının artmasına önemli katkı sağlayacaktır.

Süt ve süt ürünleri içerdikleri protein, karbonhidrat, yağ, mineral maddeler ve vitaminler nedeniyle yeterli ve dengeli beslenme için önemli gıda maddeleridir (Metin 1996). Son y1llarda yapılan klinik ve biyokimyasal araştırmalar, süt tüketiminin özellikle de az yağlı sütlerin, hipertansiyon, diş hastalıkları, kolon kanseri ve kalp hastalıklarının azalmasında önemli olduğunu göstermiştir (Gurr 1992; Massey 2001; Bus \& Worsley 2003). Günde tüketilen 1 litre süt, yetişkinlerin günlük kalsiyum ve fosfor ihtiyaçlarının tamamını, çocuklarda tamamına yakınını, yine yetişkin ve çocukların günlük riboflavin (Vitamin $\mathrm{B}_{2}$ ) ve kobalamin $\left(\mathrm{B}_{1}\right)$ ihtiyaçlarını tümünü, protein gereksinimlerinin yarısını karşılamaktadır (Özcan et al 1998).

Süt ve süt ürünleri içinde önemli bir yere sahip olan içme sütü tüketim miktarları incelendiğinde, gelişmiş ve gelişmekte olan ülkeler arasında önemli farklılıkların olduğu görülmektedir. Avusturalya, İsviçre, $\mathrm{ABD}$, Kanada ve $\mathrm{AB}$ gibi gelişmiş ekonomilerde kişi başına içme sütü miktarı sırasıyla $108.9 \mathrm{~kg}, 95.0 \mathrm{~kg}, 92.7 \mathrm{~kg}, 91.9 \mathrm{~kg}, 67.4 \mathrm{~kg}$ iken, Endonezya, Malezya, Çin, Hindistan ve Brezilya gibi gelişmekte olan ülkelerde sırası ile $1.5 \mathrm{~kg}, 2.1$ $\mathrm{kg}, 11.5 \mathrm{~kg} 42.3 \mathrm{~kg}$ ve $59.6 \mathrm{~kg}$ 'dır (FABRI 2011). Diğer taraftan Türkiye'de ise kişi başına düşen içme sütü miktarı 2007 yılında $14.8 \mathrm{~kg}$ iken 2013 
y1lında 18.4 kg'a yükselmiştir. Nüfusunun \% 33.4'ü 20 yaşın altında olan Türkiye için bu sonuç oldukça düşüktür. Ancak 2012 yılında başlatılan Okul Sütü Projesi ile Türkiye'de kişi başına düşen içme sütü miktarının artırılmasında katkıda bulunabileceği söylenebilir.

Diğer önemli bir süt ürünü olan peynirin kişi başına tüketim miktarı gelişmiş ülkeler olan İsviçre, AB, ABD, Avusturalya ve Kanada'da sirasiyla 21.8 $\mathrm{kg}, 18.0 \mathrm{~kg}, 15.0 \mathrm{~kg}, 10.7 \mathrm{~kg}$ ve $9.5 \mathrm{~kg}$ iken gelişmekte olan ülkeler Çin, Malezya, Meksika, Brezilya ve Rusya'da sirasiyla $0.2 \mathrm{~kg}, 0.3 \mathrm{~kg} 2.7 \mathrm{~kg}, 3.3 \mathrm{~kg}$ ve 5.5 kg'dır (FABRI 2011). Gelişmiş ve gelişmekte olan ülkelerde kişi başına peynir tüketiminde önemli farklar görülmektedir. Türkiye'de ise kişi başına peynir tüketimi 2007 y1lında $3.1 \mathrm{~kg}$ iken, 2013 yılında 7.8 kg'a yükselmiştir. Kişi başına peynir tüketiminde meydana gelen bu yükselişte, gelirde meydana gelen artışın yanı sıra peynir üretiminin ve ürün çeşitliliğinin artmasının da önemli etkisinin olduğu söylenebilir.

Türklerin dünyaya armağan ettiği, hemen hemen her çeşit sütten yapılabilen ekşi bir süt ürünü olan yoğurt, önemli bir kalsiyum, magnezyum ve fosfor kaynağıdır (Kılıç 2003). Dünyada yoğurt üretim ve tüketimi son yıllarda giderek artmaktadır. 2004 ve 2008 yılları arasında yoğurt tüketimi AB ülkelerinde ortalama \% 16 oranında artarken, bu artı̧̧ İtalya'da \% 43 olarak gerçekleşmiştir. Dünyada kişi başına yoğurt tüketimi $\mathrm{AB}$ ülkelerinde ortalama $20 \mathrm{~kg}$ (Carlucci et al 2013), ABD'de $6.7 \mathrm{~kg}$ ve Türkiye'de 14.3 kg'dır. Türkiye'de kişi başına yoğurt tüketimi hesaplanırken evde yapılan yoğurtlar dikkate alınmadığından kişi başına düşen yoğurt tüketimin $14.3 \mathrm{~kg}$ 'dan daha fazla olduğu söylenebilir.

Ekonomik gelişmişlikle doğru orantılı olarak, toplam harcamalar içinde gıda harcamalarının payı giderek azalmaktadır. Türkiye'de 2002 yılında toplam harcamalar içinde gida harcamalarının pay1 \% 26.7 iken bu oran 2012 yılında \% 19.6'ya gerilemiştir (TÜİK 2014b). Bu sonuç arzu edilen bir durumdur. Diğer bir ifadeyle, gelir arttıkça gıda maddelerine yapılan harcamalar mutlak olarak artarken oransal olarak azalmaktadır. Örneğin
ABD, Kanada, Almanya, İsveç ve Danimarka gibi gelişmiş ülkelerde bu oran sırasıyla \% 9.7, \% 11.7, $\% 13.1, \% 13.3$ ve \% 14.0 iken, az gelişmiş ülkeler olan Tanzanya, Nijerya, Ermenistan, Senegal ve Misir'da sirasiyla \% 73.2, \% 72.9, \% 69.7, \% 53.4 ve $\% 48.1$ 'dir (IMAP 2010).

Bu çalışmada, Türkiye'de kişi başına düşen gelirde meydana gelen artışın, zorunlu gıda maddesi olan ve doyuma ulaşmayan, süt ve süt ürünleri tüketim harcamalarında nasıl bir etkiye neden olduğu ve gelir dışında diğer sosyo-demografik ve ekonomik faktörlerin hane halkı süt ve süt ürünleri tüketim harcamalarına etkilerini Çok Değişkenli Heckman Örneklem Seçicilik Sistem (ÇDHÖS) yardımı ile ortaya konulması amaçlanmıştır. ÇDHÖS harcama olasılıkları ile harcama düzey eşitliklerinin her birinin kendi içindeki çapraz korelasyon ilişkilerini tahminlemekle yetinmeyip, her iki eşitlik grubunun (harcama olasılıkları ile harcama düzey eşitlikleri) karşılıklı çapraz korelasyon katsayılarını da ortaya koymakla önem kazanmaktadır. Ayrıca, bağımsız değişkenlerin her bir gıdanın harcama olasılıkları ile harcama düzeyleri üzerindeki birimsel etkilerde hesaplanmıştır. $\mathrm{Bu}$ birimsel etkiler ulusal politika yapıcılarına ve aynı zamanda sektörde faaliyet gösteren işverenlere karar alma süreçlerinde rehberlik edecektir.

\section{Materyal ve Yöntem}

Çalışmada kullanılan veriler, Türkiye İstatistik Kurumu (TÜIK) tarafindan 2010 yılında yapılan Hane Halkı Bütçe Harcamaları Anketlerinden (HHBHA) elde edilmiştir. Tüketim üzerine mevsimsel etkileri en aza indirmek için anketler, 1 Ocak-31 Aralık 2010 tarihleri arasında her ay benzer sosyo-demografik özelliklere sahip ailelerle yapılmıştır. Örnek büyüklüğü eksik ve aykırı gözlemler çıkarıldıktan sonra 9442 kişi olarak belirlenmiştir.

Hane halkı ve hane reisine ait sosyo-demografik özellikler Çizelge 1'de verilmiştir. Hane reisine ait sosyo-demografik özellikler cinsiyet, medeni durum, çalışıp çalışmama, yaş grubu, eğitim yılı ve zorunlu sağlık sigortası iken, hane halkına 


\section{Çizelge 1- Değişken tanımları ve örnek istatistikleri}

Table 1-Variable definitions and sample means

\begin{tabular}{|c|c|c|c|}
\hline \multirow[b]{2}{*}{ Değişken } & \multirow[b]{2}{*}{ Tanımı } & \multicolumn{2}{|c|}{ Ortalama (Std. sapma) } \\
\hline & & Kentsel & Kirsal \\
\hline \multicolumn{4}{|c|}{ Bağımlı değişkenler Harcama $\left(\right.$ TL Ay $\left.^{-1}\right)$} \\
\hline \multirow[t]{2}{*}{ Süt harcaması } & & $11.07(12.24)$ & $9.59(13.00)$ \\
\hline & Tüketenlerin arasında $(\%)$ & 82.16 & 70.80 \\
\hline \multirow[t]{2}{*}{ Yoğurt harcaması } & & $10.34(10.63)$ & $12.22(15.93)$ \\
\hline & Tüketenlerin arasında $(\%)$ & 79.45 & 68.09 \\
\hline \multirow[t]{2}{*}{ Peynir ile diğer süt ürünleri } & & $21.42(20.49)$ & $17.94(22.17)$ \\
\hline & Tüketenlerin arasında (\%) & 86.95 & 71.91 \\
\hline \multicolumn{4}{|l|}{ Sürekli açıklayıcı değişkenler } \\
\hline Aile eşdeğer büyüklüğü & & $2.16(0.69)$ & $2.28(0.91)$ \\
\hline Eğitim yılı & & $7.57(4.37)$ & $5.17(3.80)$ \\
\hline Teknoloji sayısı & & $6.31(2.60)$ & $4.79(2.27)$ \\
\hline Otomobil sayıs1 & & $0.35(0.48)$ & $0.26(0.44)$ \\
\hline Gayrimenkul sayıs1 & & $0.97(0.95)$ & $1.65(1.07)$ \\
\hline \multicolumn{4}{|c|}{ İkili açıklayıcı değişkenler (evet= 1 ; hayır $=0$ ) } \\
\hline Cinsiyet (erkek) & & 0.86 & 0.84 \\
\hline Medeni durum (evli) & & 0.86 & 0.84 \\
\hline Çalışma durumu & & 0.66 & 0.71 \\
\hline Yaş 20-29 & & 0.08 & 0.05 \\
\hline Yaş 30-39 & & 0.25 & 0.19 \\
\hline Yaş 40-49 & & 0.28 & 0.23 \\
\hline Yaş 50-59 & & 0.20 & 0.23 \\
\hline Yaş $60+$ (referans grup) & & 0.19 & 0.30 \\
\hline Zorunlu sigorta & & 0.84 & 0.64 \\
\hline Yeşil kart & & 0.07 & 0.23 \\
\hline Diğer (sigortasız) (referans grup) & & 0.09 & 0.13 \\
\hline Apartmanda yaşama & & 0.69 & 0.19 \\
\hline Çocuklu aile & & 0.59 & 0.43 \\
\hline Çocuksuz aile & & 0.14 & 0.19 \\
\hline Ev sahipliği & & 0.56 & 0.75 \\
\hline Kirac1 & & 0.28 & 0.09 \\
\hline Diğer (referans grup) & & 0.16 & 0.16 \\
\hline Çocuk 0-5 & & 0.27 & 0.27 \\
\hline Çocuk 6-14 & & 0.40 & 0.40 \\
\hline Çocuk 15-19 & & 0.26 & 0.28 \\
\hline Ayni ve nakdi destek alma & & 0.07 & 0.14 \\
\hline Gelir grubu $<15$ bin $\mathrm{TL}$ & & 0.29 & 0.55 \\
\hline Gelir grubu $15-30$ bin TL & & 0.44 & 0.32 \\
\hline Gelir grubu $31-45$ bin TL & & 0.16 & 0.09 \\
\hline Gelir grubu $>45$ bin $\mathrm{TL}+$ & & 0.11 & 0.04 \\
\hline Örnek sayıs1 & & 6452 & 2990 \\
\hline
\end{tabular}


ait özellikler teknoloji sayısı (evde kullanılan bilgisayar, cep telefonu, internet, uydu ve TV vb.), gayrimenkul varlığı, gelir grubu, eve sahip olup olmama, çocukların yaş gruplarına göre dağılımı ve aile eşdeğer büyüklüğüdür (OECD yeni aile eşdeğer büyüklüğ̈̈; hane reisi için 1.0, her bir yetişkin için 0.5 ve 14 yaşından küçük her bir çocuk için 0.3 değerleri dikkate alınarak hesaplanmıştır).

Süt, yoğurt, peynir ile diğer süt ürünlerine yapılan harcamalar aylık olarak verilmiştir. Kentsel alanda yaşayan aileler süt (11.07 TL), peynir ile diğer süt ürünlerinde $(21.42 \mathrm{TL})$ kırsal alanda yaşayan ailelere göre (9.59 TL, 17.94 TL) daha fazla harcama yaparken, kırsal alanda yaşayanlar da yoğurtta (12.22 TL) kentsel alana göre (10.34 TL) daha fazla harcama yapmaktadır. Kentsel alanda, hanelerin $\%$ 82.16's1 süt, $\% 79.45$ 'i yoğurt ve $\% 86.95$ 'i peynir ve diğer süt ürünleri harcaması yaparken kırsal da bu oranlar sirasiyla \% 70.80, \% 68.09 ve \% 71.91'dir. Bilgic \& Yen (2014)'e göre kentsel alandaki ailelerin \% 84.48'i süt ve \% 83.92'si peynir tüketmektedir. Fuller et al (2007)'e göre kentsel alandaki hanelerin \% 90.4'ü süt ve \% 58.9'u yoğurt harcaması yapmaktadır. Obayelu et al (2009)'a göre kentsel alandaki hanelerin \% 31.3'ü, kırsal alanda ise hanelerin \% 17.8 'i süt tüketmektedir. Eğitim, teknoloji ve otomobil ortalaması kentsel alanda daha yüksekken, gayrimenkul ortalaması kırsal alanda daha yüksektir. Kırsal alanda yeşil karta sahip olma (\% 23) kentsel alana (\% 7) göre daha yüksektir.

Bu çalışmada, Stewart \& Yen (2004) ve Yen (2005) tarafından kullanmış olan örneklem seçicilik sistemi (Sample Selection System, SSS) üç adet bağımlı değişken olan süt, yoğurt ve peynir ile diğer mandıra harcama gruplarına uygulamıştır. Her biri harcama miktarı eşitliği olan $y_{i}^{\prime}$ 'nin ikili (binary) örneklem seçicilik kuralı ile ortaya konulduğu üçsonuç eşitlik sistemi Eşitlik 1, 2 ve 3 'te verilmiştir.

$$
\begin{aligned}
& \log y_{i}=x^{\prime} \beta_{i}+v_{i} \text { eğer } z^{\prime} \alpha_{i}+u_{i}>0 \\
& y_{i}=0 \quad \text { eğer } z^{\prime} \alpha_{i}+u_{i} \leq 0
\end{aligned}
$$

Burada; $i=1,2,3$ sırasıyla süt, yoğurt ve peynir ile diğer mandıra harcama düzey denklemlerini göstermektedir; $z$ ve $x$ bağımsız değişkenlerinin sütün vektörünü; $\alpha_{\mathrm{i}}$ ve $\beta_{\mathrm{i}}$ uygun parametre vektörlerini ve $u_{\mathrm{i}}$ ve $v_{\mathrm{i}}$ sırasiyla harcama olasılıkları ve harcama düzey eşitlik kalıntılarını ifade etmektedir. Art arda eklenmiş altı boyutlu hata vektörü $\left[u^{\prime}, v^{\prime}\right]^{\prime}=\left[u_{1}, u_{2}, u_{3}, v_{1}, v_{2}, v_{3}\right]^{\prime} \quad$ ortalamalar1 sifir ve standart sapmaları ile korelasyon katsayısı matrisi sirasiyla $\left[1,1,1, \sigma_{1}, \sigma_{2}, \sigma_{3}\right]$ ve $R=\left[\rho_{i j}\right]$ normal dağılıma uyduğu varsayılmıştır.

Eşitlik sisteminin eşit olamayan varyans ve normal dağılımına uygunluğunun sağlamasında her bir harcama eşitliğinin doğal logaritması alınmıştır (Yen 2005). Eşitlik sisteminde üç rejim bulunmaktadır: 1) Üç gıdanın tümüne harcama yapanlar, 2) Üç gida türünün hiç birine harcama yapmayanlar (tüketmeyenler) ve 3) Diğer birleşim (en az bir ve en fazla iki olacak şekilde üç gıda türüne yapılan harcamalardan oluşan kombinasyon). Birinci rejim olan üç ürünün hepsini tüketenlerin veya diğer bir ifade ile pozitif rejim için örneklem olabilirlik katkısı Eşitlik 2'de verilmiştir.

$$
\begin{array}{r}
L=\left(\prod_{i=1}^{3} y_{i}^{-1} \sigma_{i}^{-1}\right) \phi_{3}\left(w_{1}, w_{2}, w_{3} ; R\right) \int_{-z^{2} \alpha_{i}}^{\infty} \int_{-z_{2}^{\prime} \alpha_{2}}^{\infty} \int_{-z^{\prime} \alpha_{3}}^{\infty} h\left(u_{1}, u_{2}, u_{3} \mid v_{1}, v_{2}, v_{3}\right) d u_{3} d u_{2} d u_{1} \quad(2) \\
\text { Burada; } w_{i}=\frac{\left(\log y_{i}-x^{\prime} \beta_{i}\right)}{\sigma_{i}} \text { ve } \phi_{3}\left(w_{1}, w_{2}, w_{3} ; R\right)
\end{array}
$$

üç değişkenli standart normal dağılım yoğunluk fonksiyonu ifade ederken, $\left(\prod_{i=1}^{3} y_{i}^{-1} \sigma_{i}^{-1}\right)$ ise $\left[v_{1}, v_{2}, v_{3}\right]^{\prime}$ 'den $\left[\log y_{1}, \log y_{2}, \log y_{3}\right]^{\prime}$ 'e Jakobiyen dönüşümünü bulundurularak diğer harcama rejimleri burada verilmemiştir, fakat rejimlerin (hiç tüketmeyenlerin ve diğer kombinasyonların) olabilirlik fonksiyonuna katkısı benzer şekilde geliştirilebilmektedir (Yen 2005). Süt ürünün harcamalarına ait standart sapmalar bazı açıklayıcı değişkenlerin bir fonksiyonu şeklinde sisteme uyarlanmış ve Eşitlik 3 'te gösterilmiştir.

$$
\sigma_{i}=\exp \left(m^{\prime} \gamma_{i}\right)
$$

Burada; exp, üstel fonksiyonu; $m$, harcama denklemlerinin standart sapmalarındaki değişkenliğinde rol oynayabilecek bağımsız değişken vektör setini ifade ederken; $\gamma$, her bir gıda harcaması için uygun parametre vektör setinin ifade etmektedir. 
Diğer taraftan olasılık, şartlı ve şartsız harcama miktarlarının beklenilen değerleri sırasıyla Eşitlik 4'te gösterildiği şekilde elde edilmiştir.

$$
\begin{aligned}
& \operatorname{Pr}\left(y_{i}\right)=\Phi\left(z^{\prime} \hat{\alpha}_{i}\right) \\
& E\left(y_{i} \mid y_{i}>0\right)=\exp \left(x^{\prime} \hat{\beta}_{i}+\frac{\sigma_{i}^{2}}{2}\right) \frac{\Phi\left(z^{\prime} \hat{\alpha}_{i}+\rho_{i i}^{u v} \sigma_{i}\right)}{\Phi\left(z^{\prime} \hat{\alpha}_{i}\right)} \\
& E\left(y_{i}\right)=\exp \left(x^{\prime} \hat{\beta}_{i}+\frac{\sigma_{i}^{2}}{2}\right) \Phi\left(z^{\prime} \hat{\alpha}_{i}+\rho_{i i}^{u v} \sigma_{i}\right)
\end{aligned}
$$

Burada; (.), kümülatif birim normal yoğunluk fonksiyonunu ifade etmektedir.

Yukarıdaki her bir eşitliğin ilgili bağımsız değişkene göre türevinin alınması, o değişkenin olasılık, şartlı ve şartsız ortalama harcama üzerindeki birimsel etkiyi vermektedir. Marjinal etkilerinin standart hataları ise delta metodu kullanılarak bulunmuştur (Yen \& Rosinski 2008).

\section{Bulgular ve Tartışma}

Kentsel ve kırsal alanda yaşayan ailelerin aynı parametre değerlerine sahip olduğunu öne süren sıfır hipotezi Olabilirlik Testi (Likelihood Ratio, LR) yardımı ile test edilmiştir. LR testi $\left(2 *\left(\log L_{1}+\log L_{2}-\log L_{p}\right)\right) \chi^{2}$ dağılımına uymakta ve $\left(m_{1}+m_{2}-m_{p}\right)$ serbestlik derecesine (sd) sahiptir, burada $m$ 'ler sirasiyla kentsel, kırsal ve havuzlanmış modellerde kullanılan parametre sayısını ifade etmektedir. Test sonucunda havuzlanmış modelin ret edilmesi gerektiği, yani her iki bölgenin farklı parametre değerlerine sahip olduğu ve dolayısıyla gözlemlerin kentsel ve kırsal alanlara ayrilarak analizlere tabi tutulması gerektiği saptanmıştır $(\mathrm{LR}=709.603 ; \mathrm{P}<0.000)$. Ayrıca, sistemin iki aşamada bağımsız bir şekilde çözülmeli savını öne süren hipotez her iki bölge için ret edilmiştir (kent için: Wald $=2583.46, \mathrm{P}<0.000$; kırsal için: Wald $=3022.23, \mathrm{P}<0.000)$. Benzer şekilde, ikili bağımsız sistemin (yalnızca ilgili gıdanın gida harcama olasılığı ile harcama miktarı arasındaki korelasyon katsayısı vardır) hipotezi her iki bölge için ret edilmiştir (kent için: Wald $=481.80$ ve $\mathrm{P}<0.000$; kırsal için: Wald $=307.47$ ve $\mathrm{P}<0.000$ ). Gıda harcamalarının varyansını açıklamada hane reisinin eğitim düzeyi ile aile eşdeğer büyüklüğü değişkenleri kullanılmış ve bunların her bir eşitlikte etkilerinin olmadığını öne süren ön sav, her iki bölge için de ret edilmiştir (kent için: Wald $=34.24$ ve $\mathrm{P}<$ 0.000; kursal için: Wald=25.57 ve $\mathrm{P}<0.000$ ).

Hem kentsel ve hem de kırsal alanda yaşayan ailelerde üç gıdanın harcama olasılıkları arasındaki korelasyon katsayıları pozitif ve istatistiki açıdan önemli bulunmuştur (Çizelge 2-3). Diğer taraftan, üç süt ürününe ait harcama düzeyleri arasındaki ilişkiye bakıldığında, her iki bölgede de bu korelasyon katsayıları pozitif ve istatistiki açından önemli bulunmuştur. Dolayısıyla, sistemde kontrol altına alınan faktörlerin dışında kalan kontrol edilemeyen değişkenlerinin toplam bileşimi üç süt ürünün hem harcama olasılıklarını hem de harcama düzeylerini pozitif yönlü etkilemektedir. Ayrıca, hem kentsel hem de kırsal alanda süt ürünün harcama düzeyi yoğurt ürünün harcama olasılığı arasında istatistiki açıdan önemli negatif yönlü ilişki bulunmuştur. Kentsel alanda yoğurt ürünün harcama düzeyi süt ve peynir ile diğer süt ürünlerinin harcama olasılıkları ile pozitif ilişki gösterirken, kırsal alanda bu durum yoğurt harcama düzeyi süt ve yoğurt harcama olasılıkları ile negatif ve peynir ile diğer süt ürünlerinin harcama olasılıkları ile pozitif bir ilişki göstermiştir. Son ürün olan peynir ile diğer süt ürünlerine yapılan harcama düzeyinin üç süt ürünün harcama olasılıkları ile olan ilişkisine bakıldığında; kentsel alanda yoğurt ürünün harcama olasılıkları ile pozitif yönlü, kendi ürünün harcama olasılığı ile negatif yönlü bir ilişki göstermiştir. Buna karşın kırsal alanda ise yalnızca kendi ürünün harcama olasılığı ile negatif bir ilişki düzeyini göstermiştir.

Sistem üzerinde açıklayıcı değişkenlerin tahmincilerinden ziyade, sistemin birim etkilerinin daha önemli olması göz önünde bulundurulmuş, tahmincilere ilişkin tartışmada bulunulmamıştır. Açıklayıcı değişkenlere ait birim (marjinal) etkiler kentsel alan için Çizelge 4'te kırsal alan için Çizelge 5'te verilmiştir. İstatistiki olarak anlamlı çıkan değişkenlere ait olasılık ve koşullu beklenilen ortalama marjinal etkiler tartışılmıştır. 
Çizelge 2- Süt ürünleri için örneklem seçicilik sisteminin en yüksek olabilirlik tahmincileri: Kentsel aileler Table 2-Maximum-likelihood estimation of sample selection system for milk products: Urban households

\begin{tabular}{|c|c|c|c|c|c|c|}
\hline \multirow{2}{*}{ Değişkenler } & \multicolumn{3}{|c|}{ Olasılık } & \multicolumn{3}{|c|}{ Düzey } \\
\hline & Süt & Yoğurt & Peynir ve diğer & Süt & Yoğurt & Peynir ve diğer \\
\hline \multirow[t]{2}{*}{ Sabit } & $0.396^{* * *}$ & 0.075 & $0.814^{* * *}$ & $1.620^{* * * *}$ & $1.896^{* * * *}$ & $2.742^{* * * *}$ \\
\hline & $(0.120)$ & $(0.120)$ & $(0.120)$ & $(0.132)$ & $(0.119)$ & $(0.076)$ \\
\hline \multirow[t]{2}{*}{ Aile eşdeğer büyük. } & $-0.082 *$ & $0.115^{* *}$ & $-0.126^{* * *}$ & 0.003 & $0.197^{\text {**** }}$ & $0.107^{* * * *}$ \\
\hline & $(0.043)$ & $(0.048)$ & $(0.042)$ & $(0.030)$ & $(0.027)$ & $(0.028)$ \\
\hline \multirow[t]{2}{*}{ Cinsiyet } & $-0.453^{* * * *}$ & -0.080 & 0.115 & 0.000 & -0.019 & 0.005 \\
\hline & $(0.080)$ & $(0.080)$ & $(0.083)$ & $(0.068)$ & $(0.048)$ & $(0.049)$ \\
\hline \multirow{2}{*}{ Medeni durum } & $0.319^{* * * *}$ & -0.015 & 0.062 & $0.137^{* *}$ & -0.010 & -0.072 \\
\hline & $(0.090)$ & $(0.091)$ & $(0.091)$ & $(0.068)$ & $(0.053)$ & $(0.056)$ \\
\hline \multirow[t]{2}{*}{ Çalışma durumu } & 0.053 & 0.014 & -0.028 & -0.031 & 0.030 & -0.060 \\
\hline & $(0.051)_{* * *}$ & $\begin{array}{l}(0.050) \\
-0.160\end{array}$ & $(0.056)^{* * *}$ & $(0.034)_{* * *}$ & $(0.029)_{* * * *}$ & $(0.031)_{* * *}$ \\
\hline Yaş 20-29 & $\begin{array}{l}-0.283 \\
(0.096)\end{array}$ & $(0.096)$ & $\begin{array}{l}-0.450 \\
(0.097)\end{array}$ & $\begin{array}{l}-0.167 \\
(0.064)\end{array}$ & $\begin{array}{l}-0.210^{* k *} \\
(0.054)\end{array}$ & $\begin{array}{l}-0.363^{* * *} \\
(0.057)\end{array}$ \\
\hline \multirow[t]{2}{*}{ Yaş 30-39 } & -0.124 & -0.119 & $-0.170^{* *}$ & -0.131 ** & $-0.168^{* * * *}$ & $-0.212^{* * *}$ \\
\hline & $(0.080)$ & $(0.078)$ & $(0.085)$ & $(0.053)$ & $(0.045)$ & $(0.047)$ \\
\hline Yaş 40-49 & $\begin{array}{r}-0.057 \\
(0.073)\end{array}$ & $\begin{array}{r}-0.115 \\
(0.072)\end{array}$ & $\begin{array}{l}-0.078 \\
(0.082)\end{array}$ & $-0.080^{*}$ & $-0.153^{* * *}$ & $-0.141^{* * *}$ \\
\hline \multirow[t]{2}{*}{ Yaş 50-59 } & -0.041 & $-0.165^{* * *}$ & $\begin{array}{l}(0.082) \\
-0.028\end{array}$ & $\begin{array}{r}(0.04 /) \\
-0.010\end{array}$ & $\begin{array}{l}(0.041) \\
-0.106 * * *\end{array}$ & ${ }^{(0.044)}{ }^{* 0.077}$ \\
\hline & $(0.065)$ & $(0.063)$ & $(0.075)$ & $(0.041)$ & $(0.037)$ & $(0.039)$ \\
\hline \multirow{2}{*}{ Zorunlu sigorta } & 0.058 & -0.001 & 0.109 & 0.066 & -0.041 & -0.019 \\
\hline & $(0.070)_{* * * *}$ & $(0.066)$ & $(0.069)_{\text {**** }}$ & $(0.043)$ & $(0.039)$ & $(0.041)$ \\
\hline \multirow[t]{2}{*}{ Yeşil kart } & $-0.358^{* * *}$ & -0.124 & $-0.313^{* * *}$ & $-0.204^{* *}$ & -0.061 & 0.005 \\
\hline & $(0.098)$ & $(0.093)$ & $(0.090)$ & $(0.080)$ & $(0.062)$ & $(0.063)$ \\
\hline Apartmanda yaşama & $0.302^{* * * *}$ & $0.164^{* * *}$ & $0.122^{* * * *}$ & -0.020 & 0.040 & -0.026 \\
\hline Cocuklu aile & $(0.045)$ & $(0.042)$ & $(0.046)$ & $(0.042)_{* * * *}$ & $(0.029)$ \#* & $(0.027)$ \\
\hline Çocuklu aile & $\begin{array}{r}0.102 \\
(0.065)\end{array}$ & $\begin{array}{r}0.061 \\
(0.061)\end{array}$ & $\begin{array}{r}0.060 \\
(0.065)\end{array}$ & $0.121^{* * * *}$ & $0.0955^{* *}$ & $\begin{array}{r}0.007 \\
(0.038)\end{array}$ \\
\hline Çocuksuz aile & 0.084 & 0.0143 & 0.055 & 0.011 & 0.079 & $0.111^{* *}$ \\
\hline & $(0.087)$ & $(0.086)$ & $(0.094)$ & $(0.056)$ & $(0.051)$ & $(0.053)$ \\
\hline Ev sahibi & $0.118^{*}$ & $0.138^{* *}$ & -0.073 & 0.052 & -0.005 & -0.018 \\
\hline & $(0.064)$ & $(0.060)$ & $(0.065)$ & $(0.036)$ & $(0.033)$ & $(0.034)$ \\
\hline Kirac1 & -0.019 & $0.145^{\text {*** }}$ & 0.019 & -0.055 & $-0.086^{* *}$ & $-0.123^{* * *}$ \\
\hline Cocuk 0-5 & $\begin{array}{c}(0.060) \\
0.438 * * *\end{array}$ & $\begin{array}{r}(0.057)^{* * * *} \\
0219^{* *}\end{array}$ & $(0.063)$ & $(0.037)^{* * *}$ & $(0.035)$ & $(0.036)$ \\
\hline & $\begin{array}{r}0.438 \\
(0.060)\end{array}$ & $(0.054)$ & $(0.057)$ & $\begin{array}{l}0.447 \\
(0.046)\end{array}$ & $\begin{array}{r}0.008 \\
(0.032)\end{array}$ & $\begin{array}{l}-0.050 \\
(0.032)\end{array}$ \\
\hline Çocuk 6-14 & $0.180^{* * * *}$ & 0.034 & -0.027 & 0.132 *** & -0.021 & $0.083^{* * *}$ \\
\hline & $(0.052)$ & $(0.047)$ & $(0.054)$ & $(0.034)$ & $(0.028)$ & $(0.030)$ \\
\hline Çocuk 15-19 & -0.129 ** & -0.051 & -0.085 & -0.040 & -0.018 & 0.053 \\
\hline & $(0.057)$ & $(0.054)$ & $(0.061)$ & $(0.039)$ & $(0.031)$ & $(0.034)$ \\
\hline Ayni ve nakdi yardım & $-0.171^{* * *}$ & -0.057 & $-0.335^{* * *}$ & -0.077 & -0.052 & -0.017 \\
\hline & $(0.080)$ & $(0.077)$ & $(0.072)$ & $(0.055)$ & $(0.053)$ & $(0.051)$ \\
\hline Eğitim yılı & 0.014 ** & 0.001 & 0.001 & $0.013^{* * *}$ & 0.002 & $0.014^{* * *}$ \\
\hline & $(0.006)_{* * * *}$ & $(0.005)_{* * * *}$ & $(0.001)_{* * * *}$ & $(0.004)$ & $(0.003)$ & $(0.003)$ \\
\hline Teknoloji sayısı & $0.054^{* * * *}$ & $0.071^{* * * *}$ & $0.081^{* * *}$ & & & \\
\hline Otomobil sayıs1 & $\begin{array}{r}(0.010) \\
-0.027\end{array}$ & $\begin{array}{l}(0.009) \\
-0.072 *\end{array}$ & $\begin{array}{r}(0.010) \\
-0.009\end{array}$ & & & \\
\hline & $(0.046)$ & $(0.043)$ & $(0.046)$ & & & \\
\hline Gayrimenkul sayısı & -0.019 & $-0.053^{* * *}$ & -0.004 & & & \\
\hline Gelir $15-30$ bin TL & $(0.028)$ & $(0.026)$ & $(0.029)$ & & & $00180^{* * * *}$ \\
\hline & & & & $\begin{array}{l}0.167 \\
(0.031)\end{array}$ & $\begin{array}{r}0.045 \\
(0.030)\end{array}$ & $\begin{array}{l}0.0189 \\
(0.027)\end{array}$ \\
\hline Gelir $31-45$ bin TL & & & & 0.198 **** & 0.124 & $0.366^{* * * *}$ \\
\hline & & & & $(0.042)$ & $(0.040)$ & $(0.038)$ \\
\hline Gelir > 45 bin TL + & & & & $0.356^{* * *}$ & $0.213^{* * *}$ & $0.559^{* * * *}$ \\
\hline Değișen varyans değișke & & & & $(0.050)$ & $(0.047)$ & $(0.044)$ \\
\hline Sabit & & & & $\begin{array}{l}-0.258^{* * *} \\
(0.052)\end{array}$ & $-0.362^{\text {*** }}$ & $\begin{array}{l}-0.186^{* * *} \\
(0.039)\end{array}$ \\
\hline Aile eşdeğer büyüklüğü & & & & $0.039 * *$ & $0.054^{* * *}$ & 0.024 \\
\hline & & & & $(0.018)$ & $(0.017)$ & $(0.014)$ \\
\hline Eğitim yıl & & & & -0.000 & $-0.006^{* * *}$ & $-0.005^{* * *}$ \\
\hline Korelasyon Katsayıları & & & & $(0.003)$ & $(0.003)$ & $(0.002)$ \\
\hline Olasılık: yoğurt & $0.130^{* * *}$ & & & & & \\
\hline Olasılık: peynir ve diğer & $\begin{array}{c}(0.026) \\
0.180^{* * * *}\end{array}$ & $0.242^{* * *}$ & & & & \\
\hline Düzey: süt & $(0.028)$ & $(0.026)$ & & & & \\
\hline Duzey: sut & $\begin{array}{r}0.185 \\
(0.268)\end{array}$ & $\begin{array}{l}-0.179 \\
(0.026) * * *\end{array}$ & $\begin{array}{r}0.019 \\
(0.030)\end{array}$ & & & \\
\hline Düzey: yoğurt & $0.094^{* * * *}$ & -0.020 & $0.069^{* * *}$ & $0.068^{* * *}$ & & \\
\hline & $(0.025)$ & $(0.211)$ & $(0.032)$ & $(0.022)$ & & \\
\hline Düzey: peynir ve diğer & 0.021 & $0.076^{* * *}$ & $-0.759^{* * *}$ & $0.076^{* * * *}$ & $0.121^{* * * *}$ & \\
\hline & $(0.020)$ & $(0.019)$ & $(0.026)$ & $(0.015)$ & $(0.016)$ & \\
\hline Log likelihood & -10.321 & & & & & \\
\hline
\end{tabular}

Parantez içindeki değerler standart hatalardır; anlamlılık düzeyleri; ***, 1\%;**, 5\%; *, 10\% 
Çizelge 3- Süt ürünleri için örneklem seçicilik sisteminin en yüksek olabilirlik tahmincileri: Kırsal aileler Table 3-Maximum-likelihood estimation of sample selection system for milk products: Rural households

\begin{tabular}{|c|c|c|c|c|c|c|}
\hline \multirow[b]{2}{*}{ Değişkenler } & \multicolumn{3}{|c|}{ Olasılık } & \multicolumn{3}{|c|}{ Düzey } \\
\hline & Süt & Yoğurt & Peynir ve diğer & Süt & Yoğurt & Peynir ve diğer \\
\hline \multirow[t]{2}{*}{ Sabit } & -0.189 & -0.497 & 0.174 & $1.596^{* * *}$ & $2.447^{* * * *}$ & $2.661^{* * *}$ \\
\hline & $(0.139)$ & $(0.133)$ & $(0.133)$ & $(0.214)$ & $(0.138)$ & $(0.128)$ \\
\hline \multirow[t]{2}{*}{ Aile eşdeğer büyük } & -0.041 & $0.242^{* * *}$ & $-0.085 *$ & $0.138^{* * *}$ & $0.129^{* * *}$ & 0.200 *** \\
\hline & $(0.053)$ & $(0.052)$ & $(0.049)$ & $(0.044)$ & $(0.042)$ & $(0.050)$ \\
\hline \multirow[t]{2}{*}{ Cinsiyet } & -0.154 & -0.184 * & 0.132 & $-0.176^{* *}$ & 0.129 & 0.106 \\
\hline & $(0.102)$ & $(0.104)$ & $(0.099)$ & $(0.086)$ & $(0.093)$ & $(0.094)$ \\
\hline Medeni durum & 0.390 *** & 0.113 & 0.137 & $0.288^{* * * *}$ & 0.020 & $-0.275^{* * *}$ \\
\hline \multirow{2}{*}{ Çalışma durumu } & $0.290^{* * * *}$ & $0.403^{\text {**** }}$ & $0.162 * *$ & $\begin{array}{r}(0.104) \\
-0.000\end{array}$ & $\begin{array}{r}(0.101) \\
0.056\end{array}$ & $\begin{array}{l}(0.099) \\
-0.139 * *\end{array}$ \\
\hline & $(0.066)$ & $(0.064)$ & $(0.067)$ & $(0.068)$ & $(0.060)$ & $(0.057)$ \\
\hline \multirow[t]{2}{*}{ Yaş 20-29 } & -0.292 * & -0.179 & -0.200 & $-0.218 *$ & -0.017 & -0126 \\
\hline & $(0.152)$ & $(0.141)$ & $(0.134)$ & $(0.116)$ & $(0.129)$ & $(0.119)$ \\
\hline \multirow[t]{2}{*}{ Yaş 30-39 } & -0.150 & -0.110 & -0.019 & 0.019 & -0.036 & -0.105 \\
\hline & $(0.106)$ & $(0.102)$ & $(0.101)$ & $(0.081)$ & $(0.091)$ & $(0.085)$ \\
\hline \multirow[t]{2}{*}{ Yaş 40-49 } & -0.135 & -0.138 & -0.098 & -0.065 & -0.022 & -0.122 \\
\hline & $(0.094)$ & $(0.090)$ & $(0.091)$ & $(0.071)$ & $(0.083)$ & $(0.077)$ \\
\hline \multirow[t]{2}{*}{ Yaş 50-59 } & 0.076 & 0.029 & -0.016 & -0.047 & -0.040 & 0.100 \\
\hline & $(0.080)$ & $(0.076)$ & $(0.078)$ & $(0.060)$ & $(0.068)$ & $(0.065)$ \\
\hline \multirow[t]{2}{*}{ Zorunlu sigorta } & $0.208^{* * *}$ & $0.138^{*}$ & $0.185^{* *}$ & -0.003 & -0.005 & -0.079 \\
\hline & $(0.082)$ & $(0.077)$ & $(0.078)$ & $(0.069)$ & $(0.070)$ & $(0.069)$ \\
\hline Yeşil kart & -0.116 & 0.001 & $-0.217^{* *}$ & -0.002 & $0.153^{*}$ & 0.239 *** \\
\hline & $(0.093)$ & $(0.091)$ & $(0.087)$ & $(0.080)$ & $(0.083)$ & $(0.087)$ \\
\hline Apartmanda yaşama & 0.174 ** & -0.087 & $0.179 * *$ & 0.063 & $-0.150 * *$ & -0.079 \\
\hline & $(0.084)$ & $(0.073)$ & $(0.087)$ & $(0.061)$ & $(0.066)$ & $(0.063)$ \\
\hline Çocuklu aile & $-0.175^{* * *}$ & $0.155^{* * *}$ & -0.065 & 0.019 & -0.095 & $0.134^{* *}$ \\
\hline Cocuksuz aile & -0.252 ** & $\begin{array}{r}(0.0 / 3) \\
0.076\end{array}$ & $\begin{array}{r}(0.077) \\
-0.142\end{array}$ & $(0.062)$ & $(0.064)$ & $(0.067)_{* *}$ \\
\hline & $(0.105)$ & $\begin{array}{l}0.070 \\
(0.099)\end{array}$ & $\begin{array}{l}-0.142 \\
(0.106)\end{array}$ & $(0.083)$ & $\begin{array}{l}-0.011 \\
(0.090)\end{array}$ & $(0.091)$ \\
\hline Ev sahibi & -0.012 & 0.044 & 0.007 & -0.016 & 0.082 & 0.057 \\
\hline & $(0.084)$ & $(0.077)$ & $(0.081)$ & $(0.057)$ & $(0.063)$ & $(0.062)$ \\
\hline Kiracı & 0.097 & $0.309^{* * *}$ & 0.166 & -0.085 & $-0.240^{* *}$ & $-0.162 *$ \\
\hline & $(0.117)$ & $(0.104)$ & $(0.120)$ & $(0.082)$ & $(0.095)$ & $(0.095)$ \\
\hline Çocuk 0-5 & $0.260^{* * * *}$ & -0.040 & -0.059 & $0.194^{* * *}$ & -0.076 & 0.045 \\
\hline & $(0.080)$ & $(0.076)$ & $(0.074)$ & $(0.065)$ & $(0.064)$ & $(0.064)$ \\
\hline Çocuk 6-14 & 0.000 & -0.049 & 0.001 & -0.082 & -0.003 & 0.089 \\
\hline & $(0.073)$ & $(0.069)$ & $(0.074)$ & $(0.055)$ & $(0.061)$ & $(0.060)$ \\
\hline Çocuk 15-19 & 0.019 & -0.081 & $-0.182^{* *}$ & -0026 & 0.0038 & 0.077 \\
\hline & $(0.074)$ & $(0.072)$ & $(0.071)$ & $(0.057)$ & $(0.061)$ & $(0.064)$ \\
\hline Ayni ve nakdi yardım & $-0.161^{* *}$ & -0.061 & $-0.132 *$ & -0.060 & 0.051 & 0.081 \\
\hline & $(0.082)$ & $(0.083)$ & $(0.078)$ & $(0.072)$ & $(0.075)$ & $(0.077)$ \\
\hline Eğitim yılı & 0.010 & $-0.018^{* *}$ & -0.003 & 0.009 & 0.004 & $0.018^{* *}$ \\
\hline & $(0.009)$ & $(0.009)$ & $(0.009)$ & $(0.007)$ & $(0.008)$ & $(0.008)$ \\
\hline Teknoloji sayısı & $0.057^{* * *}$ & 0.015 & $0.069^{* * * *}$ & & & \\
\hline Otomobil sayısı & $\begin{array}{r}(0.016) \\
0.087\end{array}$ & $\begin{array}{c}(0.013) \\
0.095\end{array}$ & $\begin{array}{r}(0.014) \\
0.051\end{array}$ & & & \\
\hline & $(0.069)$ & $(0.056)$ & $(0.061)$ & & & \\
\hline Gayrimenkul sayısı & $0.066^{* *}$ & $0.067^{* *}$ & 0.019 & & & \\
\hline Gelir $15-30$ bin TL & $(0.031)$ & $(0.026)$ & $(0.029)$ & $0.143^{* * * *}$ & $\begin{array}{r}0.036 \\
(0.049)\end{array}$ & $0.144^{* * *}$ \\
\hline Gelir $31-45$ bin TL & & & & $0.261^{* * *}$ & 0.102 & $0.287^{* * *}$ \\
\hline & & & & $(0.075)$ & $(0.072)$ & $(0.078)$ \\
\hline Gelir $>45$ bin TL+ & & & & 0.192 * & 0.055 & 0.323 *** \\
\hline Reŏisen yarvans deŏickenleri & & & & $(0.103)$ & $(0.099)$ & $(0.106)$ \\
\hline Sabit & & & & $-0.317^{* * * *}$ & 0.093 & 0.004 \\
\hline & & & & $(0.070)$ & $(0.070)$ & $(0.066)$ \\
\hline Aile eşdeğer büyüklüğü & & & & $0.070^{* * * *}$ & -0.024 & 0.043 \\
\hline Eăitim y1li & & & & $\begin{array}{r}(0.021) \\
0.002\end{array}$ & $\begin{array}{l}(0.021) \\
-0.003\end{array}$ & $\begin{array}{l}(0.022)^{*} \\
-0.014 * * *\end{array}$ \\
\hline & & & & $(0.005)$ & $\begin{array}{l}-0.003 \\
(0.005)\end{array}$ & $\begin{array}{l}-0.014 \\
(0.005)\end{array}$ \\
\hline Korelasyon katsayıları & & & & & & \\
\hline Olasılik: yoğurt & $\begin{array}{l}0.239^{* * *} \\
(0.033)\end{array}$ & & & & & \\
\hline Olasılık: peynir ve diğer & $0.239^{* * *}$ & $0.313^{* * * *}$ & & & & \\
\hline & $(0.033)$ & & & & & \\
\hline Düzey: süt & $\begin{array}{r}0.228 \\
(0.297)\end{array}$ & $\begin{array}{l}-0.122^{* * *} \\
(0.048)\end{array}$ & $\begin{array}{r}0.038 \\
(0.044)\end{array}$ & & & \\
\hline Düzey: yoğurt & $-0.057^{*}$ & $-0816^{* * *}$ & $-0.079^{* * *}$ & $0.0182^{* * * *}$ & & \\
\hline & $(0.030)$ & $(0.031)$ & $(0.029)$ & $(0.028)$ & & \\
\hline Düzey: peynir ve diğer & 0.006 & -0.043 & $-0.787^{* * *}$ & $0.068^{* * * *}$ & $0.086^{* * *}$ & \\
\hline & $(0.030)$ & $(0.028)$ & $(0.034)$ & $(0.024)$ & $(0.023)$ & \\
\hline Log likelihood & -9.623 & & & & & \\
\hline
\end{tabular}

Parantez içindeki değerler standart hatalardır; anlamlılık düzeyleri; ***, $1 \% ; * *, 5 \% ; *, 10 \%$ 
Çizelge 4- Açıklayıcı değişkenlerin marjinal etkileri: Kentsel alan

Table 4- Marginal effects of explanatory variables: Urban households

\begin{tabular}{|c|c|c|c|c|c|c|c|c|c|}
\hline \multirow[b]{2}{*}{ Değişkenler } & \multicolumn{3}{|c|}{ Süt } & \multicolumn{3}{|c|}{ Yoğurt } & \multicolumn{3}{|c|}{ Peynir ve diğer süt ürünleri } \\
\hline & $P$ & $C$ & $U$ & $P$ & $C$ & $U$ & $P$ & $C$ & $\mathrm{U}$ \\
\hline Sabit & $\begin{array}{l}9.697^{\text {*** }} \\
(2.934)\end{array}$ & $\begin{array}{l}18.128^{\text {**** }} \\
(2.151)\end{array}$ & $\begin{array}{l}16.451 \\
(1.854)\end{array}$ & $\begin{array}{r}2.082 \\
(3.351)\end{array}$ & $\begin{array}{l}21.886 \\
(1.967)\end{array}$ & $\begin{array}{l}17.815^{\text {**** }} \\
(1.645)\end{array}$ & $\begin{array}{l}16.039^{* * *} \\
(2.348)\end{array}$ & $\begin{array}{l}67.545 \\
(2.038)\end{array}$ & $\begin{array}{l}63.365^{* * * *} \\
(1.888)\end{array}$ \\
\hline Cinsiyet & $\begin{array}{l}-9.334^{\text {**** }} \\
(1.358)^{2}\end{array}$ & $\begin{array}{r}0.275 \\
(0.714)\end{array}$ & $\begin{array}{l}-0.955 \\
(0.674)\end{array}$ & $\begin{array}{l}-2.175 \\
(2.106)\end{array}$ & $\begin{array}{r}-0.25 \\
(0.620)\end{array}$ & $\begin{array}{l}-0.485 \\
(0.573)\end{array}$ & $\begin{array}{r}2.37 \\
(1.788)\end{array}$ & $\begin{array}{r}0.821 \\
(1.031)\end{array}$ & $\begin{array}{r}1.266 \\
(1.018)\end{array}$ \\
\hline Medeni durum & $\begin{array}{l}8.678^{* * * *} \\
(2.696)\end{array}$ & $\begin{array}{l}1.463 \\
(0.720)\end{array}$ & $\begin{array}{l}2.252 \\
(0.647)\end{array}$ & $\begin{array}{r}-0.42 \\
(2.510)\end{array}$ & $\begin{array}{l}-0.127 \\
(0.687)\end{array}$ & $\begin{array}{l}-0.157 \\
(0.636)\end{array}$ & $\begin{array}{r}1.249 \\
(1.885)\end{array}$ & $\begin{array}{l}-1.329 \\
(1.252)\end{array}$ & $\begin{array}{c}-0.868 \\
(1.210)\end{array}$ \\
\hline Çalışma durumu & $\begin{array}{r}1.311 \\
(1.267)\end{array}$ & $\begin{array}{l}-0.434 \\
(0.430)\end{array}$ & $\begin{array}{l}-0.193 \\
(0.397)\end{array}$ & $\begin{array}{r}0.376 \\
(1.388)\end{array}$ & $\begin{array}{r}0.379 \\
(0.375)\end{array}$ & $\begin{array}{r}0.352 \\
(0.347)\end{array}$ & $\begin{array}{r}-0.542 \\
(1.088)\end{array}$ & $\begin{array}{l}-1.596 \\
(0.692)\end{array}$ & $\begin{array}{l}-1.538 \\
(0.688)\end{array}$ \\
\hline Yaş 20-29 & $\begin{array}{l}-7.718 \text { *** } \\
(2.880)\end{array}$ & $\begin{array}{l}-1.813^{* * * *} \\
(0.694)\end{array}$ & $\begin{array}{l}-2.397 \\
(0.623)\end{array}$ & $\begin{array}{r}-4.71 \\
(2.963)\end{array}$ & $\begin{array}{l}-2.45^{* * * *} \\
(0.579)\end{array}$ & $\begin{array}{l}-2.476 \\
(0.543)\end{array}$ & $\begin{array}{l}-10.884 \\
(2.772)\end{array}$ & $\begin{array}{l}-9.532 \\
(0.833)\end{array}$ & $\begin{array}{l}-10.096^{* * * *} \\
(0.846)\end{array}$ \\
\hline Yaş 30-39 & $\begin{array}{l}-3.119 \\
(2.085)\end{array}$ & $\begin{array}{l}-1.544^{\text {*****}} \\
(0.627)\end{array}$ & $\begin{array}{l}-1.673^{\text {****}} \\
(0.576)\end{array}$ & $\begin{array}{l}-3.384 \\
(2.287)\end{array}$ & $\begin{array}{l}-2.085^{\text {**** }} \\
(0.533)\end{array}$ & $\begin{array}{l}-2.074^{\text {****}} \\
(0.497)\end{array}$ & $\begin{array}{l}-3.521 \\
(1.841)\end{array}$ & $\begin{array}{l}-5.678^{* * *} \\
(0.913)\end{array}$ & $\begin{array}{l}-5.738^{* * *} \\
(0.922)\end{array}$ \\
\hline Yaş 40-49 & $\begin{array}{l}-1.421 \\
(1.835)\end{array}$ & $\begin{array}{l}-0.975 \text { " } \\
(0.586)\end{array}$ & $\begin{array}{l}-0.995 \\
(0.539)\end{array}$ & $\begin{array}{l}-3.265 \\
(2.103)\end{array}$ & $\begin{array}{l}-1.915 \\
(0.499)\end{array}$ & $\begin{array}{l}-1.929^{\text {**** }} \\
(0.465)\end{array}$ & $\begin{array}{l}-1.571 \\
(1.679)\end{array}$ & $\begin{array}{l}-3.649 \\
(0.899)\end{array}$ & $\begin{array}{l}-3.563 \\
(0.910)\end{array}$ \\
\hline Yaş 50-59 & $\begin{array}{l}-1.008 \\
(1.632)\end{array}$ & $\begin{array}{l}-0.103 \\
(0.525)\end{array}$ & $\begin{array}{l}-0.216 \\
(0.484)\end{array}$ & $\begin{array}{l}-4.775^{\text {**** }} \\
(1.890)\end{array}$ & $\begin{array}{l}-1.34^{* * *} \\
(0.441)\end{array}$ & $\begin{array}{l}-1.652^{\text {*****}} \\
(0.414)\end{array}$ & $\begin{array}{r}-0.562 \\
(1.516)\end{array}$ & $\begin{array}{l}-1.928 \\
(0.802)\end{array}$ & $\begin{array}{l}-1.826^{* *} \\
(0.823)\end{array}$ \\
\hline Zorunlu s & $\begin{array}{r}1.413 \\
(1.771)\end{array}$ & $\begin{array}{r}0.795 \\
(0.521)\end{array}$ & $\begin{array}{c}0.841 \\
(0.484)\end{array}$ & $\begin{array}{l}-0.274 \\
(1.824)\end{array}$ & $\begin{array}{l}-0.537 \\
(0.513)\end{array}$ & & $\begin{array}{r}2.239 \\
(1.478)\end{array}$ & & $\begin{array}{r}0.73 \\
(0.830)\end{array}$ \\
\hline Yeşil kart & $\begin{array}{l}-10.073^{* * * *} \\
(3.056)\end{array}$ & $\begin{array}{l}-2.169^{\text {**** }} \\
(0.759)\end{array}$ & $\begin{array}{l}-2.927 \\
(0.663)\end{array}$ & $\begin{array}{l}-3.592 \\
(2.803)\end{array}$ & $\begin{array}{l}-0.777 \\
(0.744)\end{array}$ & & $\begin{array}{l}-7.174^{* * * *} \\
(2.357)\end{array}$ & $\begin{array}{l}-1.921 \\
(1.210)\end{array}$ & $\begin{array}{l}-3.257^{* * * *} \\
(1.109)\end{array}$ \\
\hline Apartmanda yaşama & $\begin{array}{c}7.803^{* * * *} \\
(1.205)\end{array}$ & $\begin{array}{l}-0.481 \\
(0.383)\end{array}$ & $\begin{array}{c}0.617 \\
(0.346)\end{array}$ & $\begin{array}{c}4.668^{* * * *} \\
(1.218)\end{array}$ & $\begin{array}{r}0.523 \\
(0.329)\end{array}$ & $\begin{array}{l}1.013^{\text {*****}} \\
(0.302)\end{array}$ & $\begin{array}{r}2.473^{\text {*****}} \\
(0.958)\end{array}$ & $\begin{array}{r}0.149 \\
(0.574)\end{array}$ & $\begin{array}{r}0.71 \\
(0.569)\end{array}$ \\
\hline Çocuklu aile & $\begin{array}{r}2.523 \\
(1.617)\end{array}$ & $\begin{array}{l}1.466^{* * * *} \\
(0.521)\end{array}$ & $\begin{array}{l}1.548 \\
(0.480)\end{array}$ & $\begin{array}{r}1.716 \\
(1.715)\end{array}$ & $\begin{array}{c}1.223 \\
(0.468)\end{array}$ & $\begin{array}{l}1.198^{* * * *} \\
(0.435)\end{array}$ & $\begin{array}{r}1.181 \\
(1.294)\end{array}$ & $\begin{array}{r}0.539 \\
(0.825)\end{array}$ & $\begin{array}{r}0.751 \\
(0.802)\end{array}$ \\
\hline Çocuksuz aile & $\begin{array}{r}1.998 \\
(1.997)\end{array}$ & $\begin{array}{r}0.082 \\
(0.727)\end{array}$ & $\begin{array}{r}0.327 \\
(0.675)\end{array}$ & $\begin{array}{c}3.805 \text { * } \\
(2.188)\end{array}$ & $\begin{array}{r}1.054 \\
(0.690)\end{array}$ & $\begin{array}{l}1.365 \\
(0.648)\end{array}$ & $\begin{array}{r}1.067 \\
(1.771)\end{array}$ & $\begin{array}{l}3.067 \\
(1.264)\end{array}$ & $\begin{array}{c}2.98 \\
(1.245)\end{array}$ \\
\hline Ev sahipliği & $\begin{array}{c}2.913 \\
(1.579)\end{array}$ & $\begin{array}{r}0.582 \\
(0.451)\end{array}$ & $\begin{array}{c}0.86 \text { ** } \\
(0.423)\end{array}$ & $\begin{array}{c}3.864 \\
(1.696)\end{array}$ & $\begin{array}{l}-0.059 \\
(0.418)\end{array}$ & $\begin{array}{r}0.452 \\
(0.398)\end{array}$ & $\begin{array}{r}-1.43 \\
(1.270)\end{array}$ & $\begin{array}{l}-0.878 \\
(0.771)\end{array}$ & $\begin{array}{l}-1.111 \\
(0.788)\end{array}$ \\
\hline Kiracı & $\begin{array}{r}-0.459 \\
(1.491)\end{array}$ & $\begin{array}{l}-0.685 \\
(0.462)\end{array}$ & $\begin{array}{l}-0.632 \\
(0.432)\end{array}$ & $\begin{array}{r}3.922 \\
(1.499)\end{array}$ & $\begin{array}{l}-1.075 \\
(0.424)\end{array}$ & $\begin{array}{l}-0.374 \\
(0.393)\end{array}$ & $\begin{array}{r}0.378 \\
(1.220)\end{array}$ & $\begin{array}{l}-2.699 \\
(0.738)\end{array}$ & $\begin{array}{l}-2.297 \\
(0.726)\end{array}$ \\
\hline Çocuk 0-5 & $\begin{array}{l}9.672 \\
(1.176)\end{array}$ & $\begin{array}{l}6.073^{* * * *} \\
(0.540)\end{array}$ & $\begin{array}{c}6.603 \\
(0.514)\end{array}$ & $\begin{array}{c}5.844 \\
(1.369)\end{array}$ & $\begin{array}{r}0.122 \\
(0.395)\end{array}$ & $\begin{array}{r}0.855 \\
(0.371)\end{array}$ & $\begin{array}{r}0.638 \\
(1.098)\end{array}$ & $\begin{array}{l}-0.957 \\
(0.683)\end{array}$ & $\begin{array}{l}-0.698 \\
(0.676)\end{array}$ \\
\hline Çocuk 6-14 & $\begin{array}{c}4.333^{\text {**** }} \\
(1.222)\end{array}$ & $\begin{array}{l}1.589 \\
(0.402)\end{array}$ & $\begin{array}{r}1.905 \\
(0.378)\end{array}$ & $\begin{array}{r}0.938 \\
(1.311)\end{array}$ & $\begin{array}{l}-0.263 \\
(0.361)\end{array}$ & $\begin{array}{r}-0.09 \\
(0.334)\end{array}$ & $\begin{array}{r}-0.527 \\
(1.071)\end{array}$ & $\begin{array}{r}1.803 \\
(0.666)\end{array}$ & $\begin{array}{l}1.465 \\
(0.671)\end{array}$ \\
\hline Çocuk 15-19 & $\begin{array}{l}-3.245^{\text {*** }} \\
(1.480)\end{array}$ & $\begin{array}{l}-0.421 \\
(0.449)\end{array}$ & $\begin{array}{l}-0.765 \\
(0.415)\end{array}$ & $\begin{array}{l}-1.431 \\
(1.533)\end{array}$ & $\begin{array}{l}-0.237 \\
(0.402)\end{array}$ & $\begin{array}{l}-0.373 \\
(0.375)\end{array}$ & $\begin{array}{l}-1.711 \\
(1.254)\end{array}$ & $\begin{array}{r}0.714 \\
(0.729)\end{array}$ & $\begin{array}{r}0.223 \\
(0.724)\end{array}$ \\
\hline Ayni ve nakdi destek & $\begin{array}{c}-4.49^{* * *} \\
(2.251)\end{array}$ & $\begin{array}{l}-0.844 \\
(0.628)\end{array}$ & $\begin{array}{l}-1.254 \\
(0.574)\end{array}$ & $\begin{array}{l}-1.609 \\
(2.236)\end{array}$ & $\begin{array}{l}-0.657 \\
(0.651)\end{array}$ & $\begin{array}{l}-0.725 \\
(0.584)\end{array}$ & $\begin{array}{l}-7.745^{\text {*** }} \\
(1.915)\end{array}$ & $\begin{array}{l}-2.525^{* * *} \\
(0.954)\end{array}$ & $\begin{array}{l}-3.874 \\
(0.868)\end{array}$ \\
\hline Aile eşdeğer büyük. & $\begin{array}{l}-2.015 \\
(1.042)\end{array}$ & $\begin{array}{r}0.459 \\
(0.432)\end{array}$ & $\begin{array}{r}0.126 \\
(0.388)\end{array}$ & $\begin{array}{l}3.195 \\
(1.322)\end{array}$ & $\begin{array}{l}2.946 \\
(0.383)\end{array}$ & $\begin{array}{r}2.774 \\
(0.357)\end{array}$ & $\begin{array}{l}-2.482 \\
(0.827)\end{array}$ & $\begin{array}{l}1.953 \\
(0.659)\end{array}$ & $\begin{array}{c}1.141 \\
(0.614)\end{array}$ \\
\hline Eğitim y1lı & $\begin{array}{c}0.346 \\
(0.140)\end{array}$ & $\begin{array}{r}0.15^{* * *} \\
(0.051)\end{array}$ & $\begin{array}{r}0.17^{* * * *} \\
(0.047)^{*}\end{array}$ & $\begin{array}{r}0.025 \\
(0.159)\end{array}$ & $\begin{array}{l}-0.022 \\
(0.051)\end{array}$ & $\begin{array}{l}-0.015 \\
(0.042)\end{array}$ & $\begin{array}{r}0.011 \\
(0.123)\end{array}$ & $\begin{array}{c}0.29^{* * * *} \\
(0.092)\end{array}$ & $\begin{array}{l}0.259^{* * * *} \\
(0.082)\end{array}$ \\
\hline Teknoloji sayısı & $\begin{array}{l}1.318 \text { *** } \\
(0.235)^{*}\end{array}$ & $\begin{array}{l}-0.038 \\
(0.055)\end{array}$ & $\begin{array}{c}0.138 \\
(0.054)\end{array}$ & $\begin{array}{l}1.987 \\
(0.262)\end{array}$ & $\begin{array}{r}0.006 \\
(0.075)\end{array}$ & $\begin{array}{c}0.261 \\
(0.063)\end{array}$ & $\begin{array}{l}1.587^{* * *} \\
(0.193)^{*}\end{array}$ & $\begin{array}{r}0.493 \\
(0.064)\end{array}$ & $\begin{array}{c}0.807 \\
(0.103)\end{array}$ \\
\hline Otomobil Sayısı & $\begin{array}{l}-0.665 \\
(1.137)\end{array}$ & $\begin{array}{r}0.019 \\
(0.045)\end{array}$ & $\begin{array}{r}-0.07 \\
(0.122)\end{array}$ & $\begin{array}{c}-1.991 \text { * } \\
(1.197)\end{array}$ & $\begin{array}{l}-0.006 \\
(0.058)\end{array}$ & $\begin{array}{l}-0.262 \\
(0.163)\end{array}$ & $\begin{array}{l}-0.173 \\
(0.896)\end{array}$ & $\begin{array}{l}-0.054 \\
(0.273)\end{array}$ & $\begin{array}{l}-0.088 \\
(0.452)\end{array}$ \\
\hline Gayrimenkul sayıs1 & $\begin{array}{l}-0.469 \\
(0.677)\end{array}$ & $\begin{array}{r}0.013 \\
(0.027)\end{array}$ & $\begin{array}{l}-0.049 \\
(0.072)\end{array}$ & $\begin{array}{l}-1.471^{* *} \\
(0.713)\end{array}$ & $\begin{array}{l}-0.004 \\
(0.048)\end{array}$ & $\begin{array}{r}-0.193 \\
(0.101)\end{array}$ & $\begin{array}{r}-0.07 \\
(0.568)\end{array}$ & $\begin{array}{l}-0.022 \\
(0.172)\end{array}$ & $\begin{array}{r}-0.036 \\
(0.289)\end{array}$ \\
\hline 0 bin TL & --- & $\begin{array}{l}2.179 \\
(0.412)\end{array}$ & $\begin{array}{l}1.827 \\
(0.346)\end{array}$ & ---- & $\begin{array}{r}0.579 \\
(0.383)\end{array}$ & $\begin{array}{r}0.464 \\
(0.307)\end{array}$ & --- & $\begin{array}{l}4.502 \\
(0.660)\end{array}$ & $\begin{array}{l}3.973 \\
(0.582)\end{array}$ \\
\hline Gelir $31-45$ bin TL & --- & $\begin{array}{r}2.735 \\
(0.618)\end{array}$ & $\begin{array}{c}2.294 \\
(0.518)\end{array}$ & --- & $\begin{array}{l}1.673^{* * * *} \\
(0.560)\end{array}$ & $\begin{array}{r}1.341 \\
(0.449)\end{array}$ & --- & $\begin{array}{l}9.755^{* * *} \\
(1.146)\end{array}$ & $\begin{array}{c}8.608 \\
(1.013)\end{array}$ \\
\hline Gelir $>45$ bin TL + & --- & $\begin{array}{r}5.296 \\
(0.851)\end{array}$ & $\begin{array}{r}4.442 \\
(0.714)\end{array}$ & --- & $\begin{array}{c}2.989^{* * *} \\
(0.716)\end{array}$ & $\begin{array}{r}2.397 \\
(0.574)\end{array}$ & ---- & $\begin{array}{l}16.557^{* * *} \\
(1.644)^{2}\end{array}$ & $\begin{array}{l}14.611 \\
(1.454)\end{array}$ \\
\hline
\end{tabular}

Parantez içindeki değerler standart hatalardır; anlamlılık düzeyleri; ***, 1\%; **, 5\%; *,10\%; P, olasılık; C, koşullu beklenilen ortalama miktar; U, koşulsuz beklenilen ortalama miktar 


\section{Çizelge 5- Açıklayıcı değişkenlerin marjinal etkileri: Kırsal alan}

Table 5-Marginal effects of explanatory variables: Rural households

\begin{tabular}{|c|c|c|c|c|c|c|c|c|c|}
\hline \multirow[b]{2}{*}{ Değişkenler } & \multicolumn{3}{|c|}{ Süt } & \multicolumn{3}{|c|}{ Yoğurt } & \multicolumn{3}{|c|}{ Peynir ve diğer süt ürünleri } \\
\hline & $P$ & $C$ & $U$ & $P$ & $C$ & $U$ & $P$ & $C$ & $\mathrm{U}$ \\
\hline \multirow[t]{2}{*}{ Sabit } & -6.336 & $17.521^{* * * *}$ & $11.829^{* * *}$ & $-17.575^{* * *}$ & $36.739^{* * *}$ & $22.368^{* * * *}$ & 5.724 & $67.584^{* * * *}$ & $50.939^{* * * *}$ \\
\hline & $(4.672)$ & $(2.746)$ & $(2.082)$ & $(4.728)$ & $(2.287)$ & (1.810) & $(4.344)$ & $(3.577)$ & $(2.979)$ \\
\hline \multirow[t]{2}{*}{ Cinsiyet } & -5.004 & -2.228 & $-2.333 *$ & $-6.281^{*}$ & 0.594 & -0.610 & 4.458 & $3.947^{* * * *}$ & $3.870^{* * * *}$ \\
\hline & (3.201) & $(1.222)$ & $(1.035)$ & $(3.419)$ & (1.298) & (1.123) & $(3.442)$ & $(1.722)$ & $(1.401)$ \\
\hline \multirow[t]{2}{*}{ Medeni durum } & $13.975^{* * * *}$ & $2.980^{* * * *}$ & $3.676^{* * *}$ & 4.083 & 1.286 & 1.528 & 4.619 & $-5.531^{* * *}$ & -2.736 \\
\hline & $(4.129)$ & $(0.987)$ & $(0.762)$ & $(4.020)$ & $(1.363)$ & (1.137) & (3.652) & $(2.431)$ & $(2.002)$ \\
\hline \multirow[t]{2}{*}{ Çalışma durumu } & $10.055^{* * * *}$ & -0.354 & $1.062^{* *}$ & $14.708^{* * *}$ & $4.238^{* * *}$ & $5.103^{* * *}$ & $5.442^{* *}$ & -1.511 & 0.267 \\
\hline & $(2.340)$ & $(0.681)$ & $(0.551)$ & $(2.389)$ & $(0.762)$ & $(0.628)$ & $(2.279)$ & $(1.259)$ & $(1.095)$ \\
\hline \multirow[t]{2}{*}{ Yaş 20-29 } & $-10.471^{* * *}$ & -2.253 & $-2.769^{* * *}$ & -6.527 & -1.759 & -2.193 & -6.923 & $-5.002 * *$ & $-5.058^{* * *}$ \\
\hline & $(5.744)$ & $(1.203)$ & $(0.983)$ & $(5.317)$ & (1.658) & (1.373) & $(4.846)$ & $(2.066)$ & $(1.760)$ \\
\hline \multirow[t]{2}{*}{ Yaş 30-39 } & -5.143 & 0.432 & -0.367 & -3.943 & -1.501 & -1.653 & -0.622 & -2.718 & -2.135 \\
\hline & $(3.720)$ & $(1.040)$ & $(0.860)$ & $(3.724)$ & $(1.257)$ & $(1.076)$ & (3.358) & $(1.738)$ & $(1.549)$ \\
\hline \multirow[t]{2}{*}{ Yaş 40-49 } & -4.604 & -0.667 & -1.061 & -4.979 & -1.535 & $-1.843^{* *}$ & -3.278 & $-3.979^{* * *}$ & $-3.654^{* * * *}$ \\
\hline & $(3.264)$ & $(0.888)$ & $(0.735)$ & $(3.284)$ & $(1.135)$ & $(0.948)$ & $(3.102)$ & $(1.548)$ & $(1.375)$ \\
\hline \multirow[t]{2}{*}{ Yaş 50-59 } & 2.531 & -0.689 & -0.180 & 1.013 & -0.417 & -0.121 & -0.533 & 2.330 & 1.570 \\
\hline & $(2.613)$ & $(0.732)$ & $(0.623)$ & $(2.662)$ & $(0.946)$ & $(0.807)$ & $(2.576)$ & $(1.523)$ & $(1.370)$ \\
\hline \multirow[t]{2}{*}{ Zorunlu sigorta } & $7.090^{* * * *}$ & -0.292 & 0.713 & $4.922 *$ & 1.102 & 1.562 * & $6.166^{* *}$ & 0.247 & 1.693 \\
\hline & $(2.819)$ & $(0.804)$ & $(0.675)$ & $(2.750)$ & $(0.986)$ & $(0.831)$ & $(2.628)$ & $(1.510)$ & (1.309) \\
\hline \multirow[t]{2}{*}{ Yeşil kart } & -3.960 & 0.113 & -0.434 & 0.032 & 2.671 ** & $1.845^{*}$ & -7.384 & $3.418^{*}$ & 0.545 \\
\hline & $(3.228)$ & $(0.993)$ & $(0.817)$ & $(3.226)$ & $(1.293)$ & (1.098) & $(3.045)$ & (1.978) & $(1.591)$ \\
\hline \multirow[t]{2}{*}{ Apartmanda yaşama } & $5.635^{* *}$ & 0.623 & 1.201 . & -3.109 & $-3.055^{* * * *}$ & -2.562 **** & $5.667^{* *}$ & 0.098 & 1.470 \\
\hline & $(2.616)$ & $(0.727)$ & $(0.658)$ & $(2.638)$ & $(0.897)$ & $(0.770)$ & $(2.640)$ & $(1.448)$ & $(1.410)$ \\
\hline \multirow[t]{2}{*}{ Çocuklu aile } & -5.903 & 0.450 & -0.443 & $5.439^{* *}$ & -0.263 & 0.721 & -2.152 & 2.559 * & 1.337 \\
\hline & $(2.642)$ & $(0.745)$ & $(0.625)$ & $(2.567)$ & $(0.924)$ & $(0.798)$ & $(2.546)$ & $(1.496)$ & $(1.323)$ \\
\hline Çocuksuz aile & -8.822 & 0.979 & -0.490 & 2.648 & 0.373 & 0.703 & -4.774 & 3.661 * & 1.397 \\
\hline & $(3.802)$ & $(1.020)$ & $(0.854)$ & $(3.415)$ & $(1.330)$ & (1.133) & (3.651) & $(2.225)$ & (1.959) \\
\hline Ev sahipliği & -0.397 & -0.199 & -0.196 & 1.558 & $1.697^{*}$ & 1.415 * & 0.215 & 1.445 & 1.111 \\
\hline & $(2.803)$ & $(0.738)$ & $(0.637)$ & $(2.702)$ & $(0.888)$ & $(0.797)$ & $(2.667)$ & $(1.332)$ & $(1.256)$ \\
\hline Kiracı & 3.173 & -1.162 & -0.458 & $10.144^{* * * *}$ & -1.418 & 0.593 & 5.214 & -2.023 & -0.286 \\
\hline & $(3.733)$ & $(0.974)$ & $(0.858)$ & $(3.131)$ & $(1.258)$ & $(1.089)$ & $(3.596)$ & $(1.974)$ & $(1.844)$ \\
\hline Çocuk 0-5 & $8.407^{* * * *}$ & $2.300^{* * *}$ & 2.836 & -1.417 & $-1.573^{*}$ & $-1.308 *$ & -1.964 & 0.405 & -0.190 \\
\hline & $(2.463)$ & $(0.817)$ & $(0.719)$ & $(2.704)$ & $(0.890)$ & $(0.792)$ & $(2.478)$ & $(1.412)$ & $(1.246)$ \\
\hline Çocuk 6-14 & 0.009 & -1.051 & -0.758 & -1.733 & -0.468 & -0.609 & 0.045 & $2.219 *$ & 1.638 \\
\hline & $(2.440)$ & $(0.692)$ & $(0.581)$ & $(2.464)$ & $(0.860)$ & $(0.743)$ & $(2.322)$ & $(1.317)$ & (1.169) \\
\hline Çocuk 15-19 & 0.626 & -0.350 & -0.173 & -2.896 & -0.072 & -0.530 & $-6.124^{* * * *}$ & -0.262 & -1.692 \\
\hline & $(2.462)$ & $(0.726)$ & $(0.609)$ & $(2.582)$ & $(0.891)$ & $(0.788)$ & $(2.446)$ & $(1.371)$ & $(1.173)$ \\
\hline Ayni ve nakdi destek & $-5.573^{*}$ & -0.568 & $-1.109^{*}$ & -2.167 & 0.328 & -0.140 & $-4.446^{*}$ & 0.428 & -0.794 \\
\hline & $(2.908)$ & $(0.854)$ & $(0.682)$ & $(3.010)$ & $(1.107)$ & $(0.939)$ & $(2.694)$ & $(1.660)$ & $(1.339)$ \\
\hline Aile eşdeğer büyük. & -1.388 & $2.578^{* * *}$ & $1.682^{* * *}$ & $8.549^{* * * *}$ & $4.138^{* * *}$ & $4.271^{* * * *}$ & $-2.792^{*}$ & $4.276^{* * *}$ & $2.446^{* * * *}$ \\
\hline & $(1.749)$ & $(0.610)$ & $(0.493)$ & $(1.816)$ & $(0.645)$ & $(0.593)$ & $(1.632)$ & $(1.163)$ & $(0.957)$ \\
\hline Eğitim y1lı & 0.333 & 0.118 & 0.128 & $-0.622^{* *}$ & -0.101 & -0.173 & -0.110 & $0.286^{*}$ & 0.182 \\
\hline & $(0.311)$ & $(0.102)$ & $(0.084)$ & $(0.308)$ & $(0.128)$ & $(0.107)$ & $(0.302)$ & $(0.168)$ & $(0.150)$ \\
\hline Teknoloji sayısı & $1.897^{* * * *}$ & -0.066 & $0.198^{* * *}$ & 0.512 & 0.124 & 0.171 & $2.266^{* * * *}$ & $0.805^{* * *}$ & $1.148^{* * * *}$ \\
\hline & $(0.527)$ & $(0.085)$ & $(0.084)$ & $(0.468)$ & $(0.120)$ & $(0.158)$ & $(0.468)$ & $(0.176)$ & $(0.241)$ \\
\hline Otomobil say1s1 & 2.902 & -0.101 & 0.302 & $3.346^{*}$ & $0.812^{*}$ & $1.115^{*}$ & 1.667 & 0.592 & 0.844 \\
\hline & $(2.306)$ & $(0.153)$ & $(0.260)$ & $(1.991)$ & $(0.489)$ & $(0.665)$ & (1.998) & $(0.714)$ & $(1.014)$ \\
\hline Gayrimenkul sayısı & 2.219 & -0.078 & 0.231 * & $2.365^{* * * *}$ & $0.574^{* * * *}$ & $0.788^{* * * *}$ & 0.621 & 0.221 & 0.315 \\
\hline & $(1.051)$ & $(0.103)$ & $(0.136)$ & $(0.933)$ & $(0.230)$ & $(0.312)$ & $(0.944)$ & $(0.333)$ & $(0.473)$ \\
\hline Gelir $15-30$ bin TL & ---- & $1.902^{* * *}$ & $1.373^{* * *}$ & --- & 0.599 & 0.413 & ---- & $3.640^{* * *}$ & $2.667^{* * *}$ \\
\hline & ---- & $(0.653)$ & $(0.472)$ & ---- & $(0.818)$ & $(0.563)$ & ---- & $(1.260)$ & $(0.924)$ \\
\hline Gelir $31-45$ bin TL & ---- & $3.768^{* * * *}$ & 2.721 & ---- & 1.767 & 1.216 & ---- & $7.958^{* * * *}$ & 5.832 \\
\hline & ---- & (1.209) & $(0.874)$ & ---- & $(1.294)$ & $(0.891)$ & ---- & $(2.444)$ & $(1.793)$ \\
\hline Gelir $>45$ bin TL + & ---- & $2.713^{*}$ & 1.959 * & ---- & 0.940 & 0.647 & ---- & $9.272^{* * *}$ & $6.795^{* * *}$ \\
\hline & ---- & $(1.592)$ & $(1.150)$ & ---- & $(1.734)$ & (1.194) & ---- & $(3.527)$ & $(2.586)$ \\
\hline
\end{tabular}

Parantez içindeki değerler standart hatalardır; anlamlılık düzeyleri; ***, 1\%; **, 5\%; *,10\%; P, olasılık; C, koşullu beklenilen ortalama miktar; U, koşulsuz beklenilen ortalama miktar 
Hane reisi erkek olanların süt tüketim olasılı̆̆g, hane reisi kadın olanlara göre kentsel alanda $\% 9.3$, kırsal alanda ise \% 5.0 oranında daha az olmuştur. Ancak bu sonuç kırsal alanda istatistiki açıdan anlamlı bulunmamıştır. Hane reisi erkek olanların yoğurt tüketim olasılığ 1 , hane reisi kadın olanlara göre kentsel alanda $\% 2.2$, kırsal alanda ise $\% 6.3$ oranında daha az olmuştur. Ancak bu sonuç kentsel alanda istatistiki açıdan anlamlı bulunmamıştır. Diğer bir ifadeyle gerek kentsel gerekse kırsal alanda hane reisi kadın olanların hem süt hem de yoğurt tüketim olasılıkları erkeklere göre daha fazla olmuştur. Trung et al (2014) kırsalda aile reisi erkek olanların kadın olanlara göre süt tüketim olasılığı ve tüketim harcamasının sirasiyla $\% 1.3$ ve $\% 2.2$ oranında daha az olduğunu belirtmiştir.

Hane reisi erkek olanların süt tüketim harcaması miktarı, hane reisi kadın olanlara göre kentsel alanda $0.28 \mathrm{TL}$ daha fazla iken, kırsal alanda 2.2 TL daha az olmuştur. Ancak bu sonuç kentsel alanda istatistiki açıdan anlamlı bulunmamıştır. Hane reisinin erkek olması süt tüketim harcama oranını (Bilgic \& Yen 2013), hane reisinin erkek olması süt ürünleri tüketim harcama oranını (Agbola 2003) düşürmektedir. Hane reisi erkek olanların peynir ile diğer süt ürünleri harcama miktarı, hane reisi kadın olanlara göre kentsel alanda $0.82 \mathrm{TL}$, kırsal alanda ise 3.9 TL daha fazla olmuştur. Ancak bu sonuç kentsel alanda istatistiki açıdan anlamlı bulunmamıştır.

Hane reisi evli olanların süt tüketim olasılığı, hane reisi evli olmayanlara göre, kentsel alanda $\%$ 8.7, kırsal alanda \% 14.0 oranında daha fazla olmuştur. Bu sonuç her iki kesim içinde istatistiki açıdan anlamlı olmuştur. Yani beklendiği gibi hane reisi evli olanların süt tüketim olasılıkları hane reisi evli olmayanlara göre daha yüksek olmuştur. Hane reisi evli olanların süt tüketim harcaması miktarı, hane reisi evli olmayanlara göre, kentsel alanda $1.5 \mathrm{TL}$, kırsal alanda 2.9 TL daha fazla olmuştur. $\mathrm{Bu}$ sonuç her iki kesim içinde istatistiki açıdan anlam olmuştur. Hane reisi evli olanların peynir ile diğer süt ürünleri harcama miktarı, hane reisi evli olmayanlara göre, kentsel alanda 1.3 TL, kırsal alanda 5.5 TL daha az olmuştur. Bu sonuç kentsel alanda istatistiki açıdan anlamlı bulunmamıştır. Bilgic \& Yen (2013; 2014)'e göre hane reisinin evli olması, hane reisi evli olmayanlara göre hem kırsal alanda hem de kentsel alanda süte yapılan tüketim harcama oranını artırırken, yoğurt ve peynire yapılan tüketim harcama oranını düşürmektedir.

Hane reisi çalışıyor olanların süt ve yoğurt tüketim olasılığı, hane reisi çalışmayanlara göre kentsel alanda sirasiyla \% 1.3 ve \% 0.4 oranında, kırsal alanda ise sirasiyla \% 10.1 ve $\% 14.7$ oranında daha fazla yüksek olmuştur. Bu sonuçlar kentsel alanda istatistiki açıdan önemsiz olmuştur. Hane reisinin çalışmıyor olması kentsel olanda süt ve süt ürünleri tüketim olasılığını önemli oranda etkilemezken, kırsal alanda oldukça etkilemiştir. Hane reisi çalışıyor olanların yoğurt tüketim harcaması miktarı, hane reisi çalışmayanlara göre kentsel alanda 0.38 TL, kırsal alanda 4.2 TL daha fazla olmuştur. Bu sonuç kentsel alan için anlamlı bulunmamıştır. $\mathrm{Bu}$ sonuçlara göre hane reisinin çalışıyor olmasının özellikle kırsal alanda temel gıda maddesi olan süt ürünleri tüketimini arttırdığ1 söylenebilir. Ancak Bilgic \& Yen (2013)'e göre aile reisinin çalışıyor olması süt, yoğurt ve peynire yapılan tüketim harcama oranlarını düşürmektedir.

Hane reisinin yaşı 20-29 arasında olan ailelerin, 60 yaş üstü hane reisi olan ailelere (referans grup) göre, süt, peynir ve diğer süt ürünleri tüketim olasılığ 1 kentsel alan için \% 7.7 ve \% 10.8, kırsal alan için \% 10.5 ve \% 7.0 daha az olmuştur. Kırsal alanda bu parametreler peynir ve diğer süt ürünleri açısından anlamlı çıkmamıştır. Kentsel alanda hane reisinin yaş 150-59 arasında olan ailelerin, referans gruba göre yoğurt tüketim olasılığı $\% 4.7$ ve hane reisinin yaşı 30-39 arasında olan ailelerin aynı şekilde referans grubundaki ailelere göre peynir ve diğer süt ürünleri tüketim olasılığ $1 \% 3.5$ oranında daha az olmuştur. $\mathrm{Bu}$ sonuçlar kırsal alan için anlamlı bulunmamıştır.

Hane reisinin yaşı 20-29 arasında olan ailelerin, referans grubundaki ailelere göre, süt, yoğurt ve peynir ile diğer süt ürünleri tüketim harcaması miktarı kentsel alan için sırasıyla 1.8 TL, $2.4 \mathrm{TL}$ ve 9.5 TL iken, kırsal alan için $2.3 \mathrm{TL}, 1.7 \mathrm{TL}$ ve 5.0 
TL daha az olmuştur. Kırsal alan için yoğurt tüketim harcaması miktarı anlamlı çıkmamıştır.

Kentsel alanda hane reisinin yaşı 20-29, 30-39, 40-49 ve 50-59 arasında olan ailelerin, 60 yaş üstü hane reisi olan ailelere göre süt tüketim harcaması miktarı sırası ile $1.8 \mathrm{TL}, 1.54 \mathrm{TL}, 0.9 \mathrm{TL}$ ve $0.1 \mathrm{TL}$, yoğurt tüketim harcaması miktarı $2.5 \mathrm{TL}, 2.1 \mathrm{TL}$, $1.9 \mathrm{TL}$ ve $1.3 \mathrm{TL}$ ve peynir ile diğer süt ürünleri tüketim harcaması miktarı 9.5 TL, 5.7 TL, 3.6 TL ve 1.9 TL daha az olmuştur.

Kırsal alanda hane reisinin yaşı 20-29 olan ailelerin temel alınan referans grubundaki ailelere göre süt tüketim harcaması miktarı $2.3 \mathrm{TL}$ daha az olmuştur. Diğer taraftan hane reisinin yaşı 40-49 arasında olan hanelerin referans grubundaki ailelere göre yoğurt tüketim harcaması miktarı $1.8 \mathrm{TL}$ ve peynir ve diğer süt ürünleri tüketim harcamas1 miktarı 4.0 TL daha az olmuştur. Bu sonuçlara göre hane reisi 60 yaş üzeri olan ailelerin hem kırsal hem de kentsel alanda diğer yaş grubunda yer alan ailelere göre daha fazla süt ve süt ürünleri tüketim olasılığ1 ve tüketim harcaması yaptıkları söylenebilir. Benzer sonuçlar Agbola (2003); Bilgic \& Yen (2013; 2014) tarafından da bulunmuştur. Buna karşın, kırsal alanda aile reisinin yaşının artmasının ailelerin süt tüketim olasılığg ve tüketim harcamasını azalttığ1 tespit edilmiştir (Trung et al 2014).

Hane reisi zorunlu sigortaya sahip ailelerin, hane reisi sigortasız olan ailelere göre süt, peynir ile diğer süt ürünlerini tüketim olasılığ 1 kentsel alanda sirasiyla \% 1.4 ve \% 2.2 daha fazla iken yoğurt tüketim olasılı̆g $1 \% 0.27$ daha az olmuştur. Fakat aynı durum kırsal alanda süt tüketim olasılığını $\%$ 7.1, yoğurt tüketim olasılı̆̆ını \% 4.9, peynir ve diğer süt ürünleri tüketim olasılığını ise $\% 6.2$ oranında artırmıştır. Bu sonuçlar kentsel alan için anlamlı olmamıştır. Zorunlu sağlık sigortasına sahip olma kırsalda süt ve süt ürünleri tüketim olasılığını yükseltmiş, kentsel alanda ise etkili olmamıştır.

Hane reisi yeşil karta sahip olan ailelerde, hane reisi sigortasız olan ailelere göre kentsel alanda süt, yoğurt, peynir ile diğer süt ürünleri tüketim olasılığı sırasıyla \% 10.1, \% 3.6 ve \% 7.2 oranında, kırsal alanda ise $\% 3.9, \% 0.03$ ve $\% 7.3$ oranında azalmıştır. Kentsel alanda yoğurt tüketim olasılığı, kırsal alanda ise süt ve yoğurt tüketim olasılığ 1 anlamlı bulunmamıştır. Hane reisinin yeşil karta sahip olması, olmayanlara göre kentsel alanda süt tüketim harcaması miktarını 2.2 TL, kırsal alanda $0.1 \mathrm{TL}$ azaltmıştır. Bu sonuç kırsal alan için anlamlı olmamıştır. Yeşil karta sahip olmak düşük gelire sahip olmanın bir göstergesi olarak düşünüldüğünde bunun sonuçlarının süt ve süt ürünleri tüketim olasılığını ve harcama miktarını kentsel alanda daha fazla etkilediği belirtilebilir.

Hane halkının apartmanda yaşıyor olması (daha modern bir yaşam) yaşamayanlara göre, kentsel alanda her bir süt ve süt ürününün tüketim olasılığını artırmaktadır. Kırsal alanda da yoğurt hariç diğer süt ve süt ürünlerinin tüketim olasıllğını artırmaktadır. Kırsal alanda yoğurt tüketim olasılığı sonucu anlamlı çıkmamıştır.

Kırsal alanda çocuklu ailelerde diğer aile tiplerine göre, süt tüketim olasıllğı $\% 5.9$ daha az iken, yoğurt tüketim olasılığ $1 \% 5.4$ daha fazla olmuştur. Kentsel alanda ise süt tüketim olasıllı̆g $1 \%$ 2.5 , yoğurt tüketim olasıllğı $\% 1.7$, peynir ile diğer süt ürünlerini tüketim olasılığı \% 1.2 daha fazla olmuştur. Ancak kentsel alan için sonuçlar anlamlı çıkmamıştır. Kentsel alanda çocuklu ailelerde diğer aile tiplerine göre süt tüketim harcama miktarı 1.5 TL, yoğurt tüketim harcama miktarı 1.2 TL, peynir ile diğer süt ürünleri harcama miktarı $0.5 \mathrm{TL}$ daha fazla olmuştur. Peynir ile diğer süt ürünleri tüketim harcama miktarı sonucu anlamlı çıkmamıştır. Teorik olarak çocuklu ailelerin daha fazla süt ve süt ürünü tüketim harcaması yapması beklenmektedir. $\mathrm{Bu}$ durum kentsel alanda gerçekleşirken kırsal alanda kısmen gerçekleşmiştir. Davis et al (2010) ailede çocuk olmasının dondurulmuş yoğurt talebini negatif, ayran talebini ise pozitif yönde etkilediğini, Gunden et al (2011) ailede çocuk olmasının açık süte göre, ambalajlı süt tüketim talebini artırdığını, Bilgic \& Yen (2014) ailede çocuk olmasının hem kırsal hem de kentsel alanda süt ve yoğurt tüketimine yapılan harcama oranlarını artırdığını, Bilgic \& Yen (2013) çocuksuz ailelerde diğer aile tiplerine göre süt tüketim harcama oranın daha düşük olduğunu, Rodolfo et al (1999) çocuksuz ailelerde süt, tereyağı, 
peynir ve diğer süt ürünlerine yapılan harcamaların daha düşük olduğunu vurgulamıştır.

Ailelerin 0-5 yaş grubu arasında çocuğu olanlarda olmayanlara göre, kentsel alanda süt tüketim olasılığı \% 9.7, yoğurt tüketim olasılığını $\% 5.8$ ve peynir ile diğer süt ürünleri tüketim olasılığını \% 0.6 oranında daha fazla ve benzer şekilde kırsal alanda süt tüketim olasılığ $\% 8.4$ oranında daha fazla olmuştur. Hem kentsel hem de kırsalda 0-5 yaş grubu çocuğa sahip olan ailelerin sahip olmayanlara göre, süt tüketim harcama miktarı kırsalda 2.3 TL, kentsel de ise 6.1 TL daha fazla olmuştur. Gerek kırsal alanda gerekse kentsel alanda 0-5 yaş grubu arasında çocuğa sahip olmak özellikle süt tüketim olasıllğg 1 ve süt tüketim harcamasını artırması beklenen bir olgudur. Elde edilen sonuçlar bu beklentiyi doğrulamaktadır. Benzer sonuçlar Davis et al (2012); Bilgic \& Yen (2013); Trung et al (2014) tarafından da vurgulanmıştır. Benzer durum 6-14 yaş grubu çocuğa sahip kentsel alanda yaşayan aileler içinde geçerlidir. Ancak özellikle kentsel alanda 15-19 yaş grubu arasında çocuğa sahip ailelerde olmayanlara göre süt, yoğurt, peynir ile diğer süt ürünleri tüketim olasılıkları sırası ile $\% 3.2, \% 1.4$ ve \% 1.7 oranında daha az olmuştur. Çocukların küçük yaşlarda daha fazla süt ve süt ürünleri tüketmesi gerektiğinden yaş arttıkça tüketim olasılığının giderek azalması beklenen bir sonuçtur. Davis et al (2012) tarafından yapılan çalışmada da 13-17 yaş grubu arasında çocuğa sahip ailelerde tam yağlı süt tüketiminin azaldı̆̆

Aile eşdeğer büyüklüğü arttıkça, kentsel alanda süt tüketim olasılığı \% 2.0, kırsal alanda \% 1.4 oranında azalmıştır. Bu sonuç kırsal alan için anlamlı çıkmamıştır. Yoğurt tüketim olasılığı kentsel alanda $\% 3.2$, kırsal alanda \% 8.5 oranında artmıştır. Peynir ile diğer süt ürünleri tüketim olasılığ \% 2.5 kırsalda \% 2.8 oranında azalmıştır. Aile eşdeğer büyüklüğü ile süt ve süt ürünleri tüketim harcama miktarı arasında gerek kırsalda gerekse kentsel alanda pozitif yönde bir ilişki olduğu gözlenmiştir. Yani aile eşdeğer büyüklüğü arttıkça süt ve süt ürünlerine yapılan harcamalar da artmıştır. Araştırma sonuçlarına göre aile eşdeğer büyüklüğü arttıkça kentsel alanda süt, yoğurt, peynir ve diğer süt ürünlerine yapılan harcama miktarını sırasıyla 0.459 TL, 2.946 TL ve $1.953 \mathrm{TL}$ artmıştır. Kırsal alan için bu miktarlar sirasiyla $2.578 \mathrm{TL}, 4.138 \mathrm{TL}$ ve 4.276 TL'dir. Çeşitli araştırıcılar, aile büyüklüğü arttıkça süt ve süt ürünlerine yapılan harcamaların arttığını belirtirken (Rodolfo et al 1999; Agbola 2003; Bopape \& Myres 2007), başka araştırıcılar ise aile büyüklüğü arttıkça süt ürünlerine yapılan tüketim harcama oranlarının düştüğünü vurgulamışlardır (Koç \& Tan 2001; Ricciuto et al 2006; Bilgic \& Yen 2013; 2014).

Eğitim yılı arttıkça kentsel alanda süt, yoğurt, peynir ile diğer süt ürünlerinin tüketim olasılıkları arasında pozitif bir ilişki olduğu belirlenmiştir. Ancak sadece süt tüketim olasılığı anlamlı çıkmıştır. Eğitim yılı bir yıl arttığında kentsel alanda süt tüketim harcaması $0.15 \mathrm{TL}$, peynir ile diğer süt ürünleri tüketim harcaması $0.29 \mathrm{TL}$ artmıştır. Benzer sonuçlar Agbola (2003); Fuller et al (2007); Bilgic \& Yen $(2013 ; 2014)$ tarafindan da tespit edilmiştir. Kırsalda eğitim yılı bir yıl arttığında peynir ile diğer süt ürünleri harcama miktarı 0.29 TL azalmıştır. Ancak Trung et al (2014)'e göre kırsalda eğitim yılı arttıkça süt tüketim olasılığı ve tüketim harcama miktarı artmaktadır.

Teknoloji sayısı kentsel alanda süt, yoğurt, peynir ile diğer süt ürünlerinin tüketim olasılıklarını sırası ile $\% 1.4, \% 2.0$ ve $\% 1.6$ oranında, kırsal alanda ise $\% 1.9, \% \quad 0.5$ ve $\% 2.3$ oranında artırmıştır. Teknolojinin sağlamış olduğu zamanında aile fertlerine ulaşabilmenin bu olasılıkta büyük bir etken olduğu tespit edilmiştir. Kırsal alanda yoğurt tüketim olasılığı anlamlı çıkmamıştır. Teknoloji sayısı hem kirsal hem de kentsel alanda peynir ile diğer süt ürünleri tüketim harcamasını sırasıyla 0.81 TL ve $0.50 \mathrm{TL}$ artırmıştır.

Sahip olunan otomobil sayısı kırsal alanda her bir grubun tüketim olasılığını artırırken, kentsel alanda her bir grubun tüketim olasılığını azaltmıştır. Hem kırsal hem de kentsel alanda yoğurt tüketim olasılığı hariç diğerleri anlamsız bulunmuştur. Sahip olunan gayrimenkul sayısı kırsal alanda süt tüketim olasılığ1 ve yoğurt tüketim olasılığını sirasıyla \% 2.2 ve \% 2.4 oranında artırırken, kentsel 
alanda süt tüketim olasılığını $\% 0.5$, yoğurt tüketim olasılığını ise \% 1.5 oranında azaltmıştır. Kentsel alan süt tüketim olasılığı hariç diğerleri anlamlı bulunmuştur. Otomobil ve gayrimenkul varlığının artması zenginliğin bir göstergesi olarak kabul edildiğinde sonuçların normal olduğu söylenebilir. Çünkü kentsel alanda yaşayanların gelirinin artması daha önceden tüketilmeyen bir takım farklı ürünlerin tüketim olasılıklarını yükseltirken, süt ve süt ürünleri gibi zorunlu malların tüketim olasılıklarını düşürebilmektedir. Kırsal kesimde yaşayanlar için ise tam tersi durum geçerlidir. Yani kısa dönemde tüketim alışkanlıkları değişmediğinden gelirleri artsa da yine süt ve süt ürünleri tüketimleri yükselebilmektedir. Kırsal alanda değişimin kentsel alana göre daha yavaş olmasının bu sonuçların çıkmasında etkili olduğu düşünülmektedir.

Gelir grubu yıllık 15-30 bin TL arasinda olanların gelir grubu yıllık 15 bin TL'den az olanlara göre, süt tüketim harcaması kentsel alanda $2.2 \mathrm{TL}$, kırsal alanda 1.9 TL daha fazla olmuştur. Aynı şekilde peynir ile diğer süt ürünleri tüketim harcama miktarı da kentselde 4.5 TL, kırsalda 3.6 TL daha fazla olmuştur. Gelir grubu yıllık 31-45 bin TL arasında olanların gelir grubu yıllık 15 bin TL'den az olanlara göre kentsel alanda her bir ürün grubuna göre sırasıyla tüketim harcamas $2.7 \mathrm{TL}, 1.7$ TL ve 9.8 TL daha fazla olmuştur. Kırsal alanda ise süt, peynir ile diğer süt ürünlerine yapılan tüketim harcamas1 3.8 TL ve 8.0 TL daha fazla olmuştur. Gelir grubu yıllık 45 bin TL ve üzerinde olanların gelir grubu yıllık 15 bin TL'den az olanlara göre kentsel alanda her bir ürün grubuna göre sirasıyla 5.3 TL, 2.9 TL ve 16.6 TL daha fazla tüketim harcaması yaptıkları belirlenmiştir. Kırsal alanda ise süt ve peynir ile diğer süt ürünlerine sırsıyla 2.7 TL ve 9.3 TL daha fazla tüketim harcaması yapıldı̆̆ belirlenmiştir. Davis et al (2012) tarafından ABD'de yapılan çalışmada da gelir grubu yıllık 19999 \$ ve aşağısındakiler ile gelir grubu yıllık 35000 \$ 49999 \$ arasinda olanların gelir grubu ortalama yıllık 20000 \$ - 34999 \$ olanlara göre daha fazla tam yağlı süt tükettiği, gelir grubu yıllık 50000 \$ ve üzerindekilerin gelir grubu yıllık 20000 \$ 34999 \$ olanlara göre daha az tam yağlı süt tükettiği tespit edilmiştir. Bunun yanı sıra Trung et al (2014) gelir artışının kırsal alanda süt tüketim olasılığ 1 ve harcamasını artırdığını vurgulamıştır. Bu sonuçlar çalışma ile paralellik arz etmektedir.

$\mathrm{Bu}$ sonuçlara göre gelir düzeyi arttıkça kentsel alanda her bir süt ve süt ürünleri grubuna yapilan tüketim harcaması mutlak olarak artarken, kırsal kesimde ise yoğurt hariç diğer ürün guruplarına yapılan tüketim harcaması mutlak olarak artış göstermiştir. Kırsalda yoğurt tüketim harcamasının önemli oranda artış göstermemesinin nedeni, kırsalda genelde ailelerin yoğurtları kendilerinin yapmasıdır. Ancak yoğurdun ana materyali olan süte yapılan tüketim harcamasının artması aslında yoğurda yapılan harcamaları da artırmaktadır.

\section{Sonuçlar}

Araştırma sonuçları, kırsal ve kentsel alandaki hanelerin sahip olduğu sosyo-demografik ve ekonomik özelliklerin süt ve süt ürünleri tüketim harcamalarını farklı şekilde etkilediğini göstermiştir. Hane halk1 ve hane reisi özelliklerinin gerek kırsal gerekse kentsel alanda hanelerin süt ve süt ürünleri tüketim olasılığı ile harcama düzeylerini belirlemede önemli bir role sahip olduğu araştırma sonuçları tarafından desteklenmiştir. Sistemin bütününde yer alan çapraz korelasyonların beklentilerle ve istatistiki açıdan önemli olması sistemin bir bütün olarak ele alınmasının doğruluğunu göstermektedir. Kentsel alanda yaşayan hanelerin, hem süt hem de peynir ile diğer süt ürünlerine, kırsal alanda yaşan hanelere göre daha fazla harcama yaptığ1 tespit edilmiştir. Buna karşın kırsal alanda yaşayan hanelerin yoğurt harcamasının kentsel alandaki hanelere göre daha yüksek olduğu bulunmuştur. Tüm süt ve süt ürünlerinde tüketim olasılıklarının kentteki hanelerde kırsala göre daha yüksek olduğu bulunmuştur.

Kentsel alanda hane reisinin erkek olması, özellikle genç olması (20-29 yaş), yeşil karta sahip olması ve ailenin kirada oturması hem süt ve süt ürünleri tüketim olasılığını hem de süt ve süt ürünleri tüketim harcamasını negatif yönde etkilerken, hane reisinin evli olması, ailenin apartmanda yaşaması, 
çocuklu aile olması, 0-5 yaş grubunda çocuğa sahip olması ve hane gelirinin y1llk 15 bin TL' den fazla olması süt ve süt ürünleri tüketim olasıllığı ve tüketim harcamasını pozitif yönde etkilemiştir. Kırsal alanda hane reisinin erkek olması, genç (20-29 yaş) olması, yeşil karta sahip olması kentsel alanda olduğu gibi hem süt ve süt ürünleri tüketim olasılığını hem de süt ve süt ürünleri tüketim harcamasını negatif yönde etkilemiştir. Buna karşın, hane reisin evli olması, çalışıyor olması, zorunlu sigortaya sahip olması, ailenin 0-5 yaş grubunda çocuğa sahip olması, gayrimenkul sayısı ve hane gelirinin yıllık 15 bin TL'den fazla olması süt ve süt ürünleri tüketim harcamasını pozitif yönde etkilemiştir.

Araştırma sonuçlarından da anlaşılacağı üzere gerek kentsel gerekse kırsal alanda hanelerin sahip oldukları sosyo-demografik ve ekonomik faktörlerin hanelerin süt ve süt ürünleri tüketim olasılığı ve tüketim harcama düzeylerini önemli ölçüde etkilemektedir. Elde edilen sonuçlarla kırsal ve kentsel verilerinin ayrı ayrı analizlerinin yapılması gerektiğini de ortaya konulmuştur. $\mathrm{Bu}$ bağlamda uygulanan modelin doğruluğunu yansitırken, havuzlanmış verilerin sapmalı, tutarsız ve etkin olmayan parametre sonuçları doğuracağı kaçınılmaz olmuştur. Ayrıca, gerek hane reisinin gerekse hanelerin sahip olduğu özellikleri olumlu yönde etkileyecek ve ekonomik gelişmeyi sürdürülebilir kılacak politikaların belirlenmesi ve uygulanmasının oldukça önemli olduğu görülmüştür. Gelişen, büyüyen istikrarlı bir ekonomide kısa dönemde hanelerin tüketim alışkanlıkları ve yapısında hızlı bir değişim olmasa da uzun dönemde mutlaka tüketici davranışlarında ve yapısında olumlu değişmeler meydana geleceği sonucuna ulaşılmıştır.

\section{Kaynaklar}

Agbola F W (2003). Estimation of food demand patterns in South Africa based on a survey of households. Journal of Agricultural and Applied Economics 35(3): 663-670

Akbay C \& Tiryaki G Y (2007). Tüketicilerin ambalajlı ve açık süt tüketim alışkanlıklarının karşılaştırmalı olarak incelenmesi: Kahramanmaraş Örneği. KSÜ Fen ve Mühendislik Dergisi 10(1): 89-96

Bilgic A \& Yen S T (2013). Household food demand in Turkey: A two-step demand system approach. Food Policy 43(6): 267-277

Bilgic A \& Yen S T (2014). Demand for meat and dairy products by Turkish households: A Bayesian censored system approach. Agricultural Economics 45(2): 117127

Bopape L \& Myers R (2007). Analysis of households demand for food in South Africa: Model selection, expenditure endogeneity and the influence of sociodemographic effects. African Econometrics Society Annual Conference 4-6 July Cape Town, South Africa

Bus A E M \& Worsley A (2003). Consumers' health perceptions of three types of milk: A survey in Australia. Appeite 40: 93-100

Carlucci D, Stasi A, Nardone G \& Seccia A (2013). Explaining price variability in the Italian yoghurt market: A Hedonic analysis. Agribusiness 29(2): 194206

Davis C G, Blayney D, Muhammad A, Yen S T \& Cooper J (2010). A cross-sectional analysis of U.S. yoghurt demand. Journal of Food Distribution Research 41(2): 36-45

Davis C G, Dong D, Blayney D, Yen S T \& Stillman R (2012). U.S. fluid milk demand: A disaggregated approach. International Food and Agribusiness Management Review 15(1): 25-50

FABRI (2011). FABRI- ISU 2011 World agricultural outlook. Food and Agricultural Policy Research Intitute, Iowa State Universtiy, Ames, Iowa, USA. http://www.fapri. iastate.edu/outlook/2011/ (Erişim tarihi: 12.05.2014)

Fuller F, Behgin J \& Rozelle S (2007). Consumption of dairy products in urban China: Results from Beijing, Shangai and Guangzhou. The Australian Journal of Agricultural Resource Economics 51: 459-474

Göğüş A K (1986). Et teknolojisi. Ankara Üniversitesi Ziraat Fakültesi Yayınları: 991, Ders Kitabı: 291, Ankara

Gurr M L (1992). Milk products: Contribution to nutrition and health. International Journal of Dairy Technology 45(3): 61-67

Gunden C, Bilgic A, Miran B \& Karl1 B (2011). A censored system of demand analysis to unpacked and prepackaged milk consumption in Turkey. Qualıty \& Quantity 45(6): 1273-1290 
IMAP (2010). Food and beverage industry global report2010. http://www.imap.com/imap/media/resources/ IMAP_Food__Beverage_Report_WEB AD6498A 02CAF $\overline{4}$.pdf (Erişim tarihi: 18.05.2014)

Kılıç S (2003). Yoğurt ve insan sağlığı. Ege Üniversitesi. Tarımsal Uygulama ve Araştırma Merkezi, Çiftçi Broşürü No: 39 İzmir

Koç A \& Tan S (2001). The demand for dairy products in Turkey: The impact of household composition on consumption. METU Studies in Development 28(1-2): 169-181

Massey L K (2001). Dairy food consumption, blood pressure and stroke. Journal of Nutrition 131(7): $1875-1878$

Metin M (1996). Süt teknolojisi. 1. Bölüm Sütün Bileşimi ve İşlenmesi. Ege Üniversitesi Mühendislik Fakültesi Yayın No: 33, İzmir

Obayelu A E, Okoruwa V O \& Oni O A (2009). Analysis of rural and urban households' food consumption differential in the North-Central, Nigeria: A microeconometric approach. Journal of Development and Agricultural Economics 1(12): 18-26

Özcan T, Erbil F \& Kurdal E (1998). Sütün insan beslenmesindeki önemi. Içme Sütü Sempozyumu Bildiriler Kitabı, Tekirdağ 31-41

Ricciuto L, Tarasuk V \& Yatchew A (2006). Sociodemographic infuluences on food purchasing among Canadian Households. European Journal of Clinical Nutrition 60: 778-790

Rodolfo M, Nayga Jr \& Siebert J W (1999). Analysis of at-home consumption of dairy products in the Unidet
States. Journal of Food Products Marketing 5(3): 6578

Stewart H \& Yen S T (2004). Changing household characteristics and the away-from home food market: A censored equation system approach. Food Policy 29(6): 643-658

TÜİK (2014a). http://www.tuik.gov.tr/PreTablo.do?alt_ $\mathrm{id}=1045$ (Erişim tarihi: 20.05.2014)

TÜİK (2014b). http://www.tuik.gov.tr/PreTablo.do?alt_ $\mathrm{id}=1012$ (Erişim tarihi: 25.05.2014)

Trung T Q, Giam D Q, Hai V T, Thao L P, Hang N T T, Son L T K \& Linh B T M (2014). Factor influencing milk consumption of rural households in Northern Vietnam. Greener Journal of Business and Management Studies 4(2): 31-40

Yaylak E, Taşkın T, Koyubenbe N \& Konca Y (2010). İzmir ili ödemiş ilçesinde kırmızı et tüketim davranışlarının belirlenmesi üzerine bir araştırma. Hayvansal Üretim 51(1): 21-30

Yen S T \& Rosinski J (2008). On the marginal effects of variables in the log transformed sample selection models. Economics Letters 100(1): 4-8

Yen S T (2005). A multivariate sample-selection model: estimation cigarette and alcohol demands with zero observations. American Journal of Agricultural Economics 87(2): 453-466

Yücel A (2001). Et ve su ürünleri teknolojisi. IV. Bask1. Uludağ Üniversitesi Ziraat Fakültesi Ders Notları No: 47, Bursa 